\title{
Work on the cutting edge: metallographic investigation of Late Bronze Age tools in southeastern Lower Austria
}

\author{
Marianne Mödlinger ${ }^{1}$ (D) $\cdot$ Peter Trebsche $^{2}$
}

Received: 24 November 2020 / Accepted: 13 June 2021 / Published online: 2 July 2021

(c) The Author(s) 2021

\begin{abstract}
This paper analyses 20 Late Bronze Age (ca 1080-800 BC) copper alloy objects to discern their manufacture and the skills of local craftsmen. Several tools and jewellery were studied that originated from a bronze workshop located immediately next to the Prigglitz-Gasteil copper ore mining site and several contemporaneous sites in the surrounding area. The samples were studied with optical microscopy (microstructurally), and SEM-EDXS and XRF (chemical analyses). Our analyses are part of a larger study and suggest that the Prigglitz region's bronze production was not standardized. Particular alloys do not seem to have been chosen for object types or due to their intended use-function. Notably, approximately $20 \%$ of the objects contain unalloyed copper inclusions, which are most likely a result of the incomplete mixing of scrap metals and alloys during their production.
\end{abstract}

Keywords Late Bronze Age $\cdot$ Eastern Alps $\cdot$ Austria $\cdot$ Mining site $\cdot$ Metallographic analysis $\cdot$ XRF analyses $\cdot$ Production of copper alloy objects $\cdot$ Chaîne opératoire

\section{Introduction}

Numerous bronze casting workshops have been found that belong to the Middle Danubian Urnfield Culture dating to the Late Bronze Age (ca 1300-800 BC) in eastern Austria, southern Moravia, southwestern Slovakia, and western Hungary (Lochner, 2013). Evidence of archaeological and metallurgical remains in these regions (e.g. casting moulds and debris and semi-finished products) shows that metalworking was concentrated in central hillforts at sites such as Szentvid near Velem (comitate of Vas), and Gór-Kápolnadomb (comitate of Vas) and Várvölgy (comitate of Zala) in western Hungary (Ilon, 1992, 1996, 2018; Müller, 2006; Czajlik, 2014). In adjacent Lower Austria, metal workshops are assumed to have existed at the hillforts Schanzberg near Thunau am Kamp (Lochner, 2004, 2017), 'Gelände' near Grünbach am

Marianne Mödlinger

marianne.moedlinger@gmail.com

Peter Trebsche

peter.trebsche@uibk.ac.at

1 Dipartimento di Chimica e Chimica Industriale (DCCI), Università degli Studi di Genova, Genoa, Italy

2 Institut für Archäologien, Leopold-Franzens-Universität Innsbruck, 6020 Innsbruck, Austria
Schneeberg (Mühlhofer, 1952; Trebsche et al., 2019, and Rauheneck near Baden (Calliano, 1894, 90). The raw metal that supplied these workshops is disputed; however recent archaeometallurgical investigations of copper alloys from the region suggest that there were likely several ore mining sites that supplied Late Bronze Age metalworkers in the Middle Danube region (Czajlik, 2013; Zachar and Salaš, 2018, 2019; Mödlinger and Trebsche, 2020).

During recent excavations at the Prigglitz-Gasteil site, in the Neunkirchen district, an extraordinary Late Bronze Age casting workshop was discovered. The site is not located at a hillfort but immediately next to a contemporaneously dated copper ore mine at the slopes of the Gahns mountain in the Schneeberg-Rax region of southeastern Lower Austria. Excavations at the site from 2010 to 2014, and subsequent geophysical surveys and core drillings from 2017 to 2018 (Trebsche, 2013, 2015b, 2015a; Trebsche and Pucher, 2013; Haubner, et al., 2019), have shown that copper ore, mainly chalcopyrite and pyrite mineralization, were extracted from opencast mines at the site during the Late Urnfield Period (Ha B, ca 1080 to $800 \mathrm{BC}$ ). The dwellings and workshops of Late Bronze Age miners and craftsmen at the site were constructed on artificial terraces cut into the heaps of mining debris. During the excavations, two terrain terraces, T3 and $\mathrm{T} 4$, were investigated in detail, yielding evidence for bronze 
casting activities. The evidence consists of numerous casting drops and fine platy slags that predominantly belong to three occupation phases: T3-10, T3-08F, and T3-08A.

On the upper terrain terrace of T3, which according to a series of radiocarbon dates, was in use from the end of the tenth century BC to the end of the ninth century BC (Trebsche, 2015b; Trebsche, in preparation), only casting waste and fragments of casting tools were found so that the spectrum of production is unknown. However, four finds from the site are important as they indicate the production of at least three categories of bronze objects: first, one fragment of a sandstone casting mould for a knife with a tang hilt (Griffdornmesser, probably type Baumgarten after Říhovský, 1972, 64-71; Trebsche, 2015b, 49, Fig. 2/7); second, one sandstone casting cone for the production of a socketed axe; third, a bronze casting cone that fits into the socket of small arrowheads, indicating on-site weapon production; fourth, a casting sprue that cannot be precisely attributed to an artefact type but is the size appropriate for casting an object like a knife, razor, or sickle (Trebsche and Pucher, 2013, 127-128, Fig. 14/2). Hence, the workshop at Prigglitz-Gasteil seems to have produced a range of artefacts that indisputably included arrowheads, knives (Griffdornmesser), and socketed axes.

No heavy tools, such as hammers, axes and pickaxes, or weapons like swords, were found at the site; only small objects such as rings, belt clips, double-pointed tools, two completely preserved knives, and two dress pins were discovered during the excavations. Nevertheless, the number of copper alloy artefacts found on terraces $\mathrm{T} 3$ and $\mathrm{T} 4$, in an area of ca $210 \mathrm{~m}^{2}$, is high at about 250 weighing a total of ca $663 \mathrm{~g}$. Most of the artefacts are remnants of the metalworking processes with ca 200 casting drops and small bronze fragments, and 23 other pieces from casting or recycling. In a recent study of the chemistry and isotopic makeup of the Prigglitz-Gasteil metal finds and copper ores, we investigated the chaîne opératoire of local copper production and bronze working, as well as the regional distribution networks of metal artefacts. In that study, we concluded that Prigglitz-Gasteil was an active copper mining, metal-making, and importation and recycling site, especially in the late tenth/ninth centuries BC. Prigglitz-Gasteil sourced metal or raw materials were exchanged at least in the Schwarza Valley's micro-region. However, additional investigations of more distant LBA sites will be necessary to fully explore the extent of exchange and the Prigglitz-Gasteil mining site's role (Mödlinger et al. 2021).

The aim of this paper is to investigate the post-casting treatment of select bronze objects to gain insight into postcasting manufacturing processes and the skills of regional craftsmen (Fig. 1). For this work, a series of 20 copper and bronze objects from the Prigglitz-Gasteil copper mining site, and the surrounding Late Bronze Age dated cemetery, cave, hilltop, and hoards, located within a radius of ca $15 \mathrm{~km}$, were selected for metallographic investigation. The 20 metallographic analyses presented in this paper are compared to objects from the Mahrerdorf Late Bronze Age hoard (Mödlinger and Trebsche 2020).

\section{Materials and methods}

\section{Selected objects and their site context}

From the numerous copper alloy fragments found at, and in one instance near, Prigglitz-Gasteil, almost all of the preserved tools with cutting edges or points were selected for metallographic analysis. These tools include a tanged Stillfried-type knife (Fig. 2: 10; cf. Říhovský, 1972, 55-58; Jiráň 2002, 59-60; Veliačik 2012, 305-306), a tanged knife that had been reworked from a fragment (Fig. 2: 9; Ŕíhovský, 1972, 76), and three double-pointed awls (Fig. 2: 1-3). One socketed axe with curved decoration (Fig. 2: 4; cf. Mayer, 1977, 192-198) was found ca $500 \mathrm{~m}$ away at Klausgraben. The jewellery selected for analysis included two belt clips (Fig. 2: 5-6), one fragment of a bracelet with a flat crosssection (Fig. 2: 7), and a rod or wand of unknown function (Fig. 2: 11). All the objects are copper-tin alloys except for a casting cake of unalloyed copper (Fig. 2: 8). Strictly speaking, the local production of the bronze artefacts cannot be proven, as chemical and lead isotope analyses have shown that mixing of different copper alloys and recycling played a significant role at the Prigglitz-Gasteil site (Mödlinger et al. 2021).

For comparison to these alloys, objects from several nearby sites were selected. The first is a gravesite at Pottschach located $5 \mathrm{~km}$ away from Prigglitz-Gasteil (Kerchler, 1960). It was chosen because the same types and decoration of dress pins are found there (Trebsche and Pucher, 2013, 122, Fig. 7/1-2). From the grave goods, two decorated tanged knives, a Velem-St. Vid type (Fig. 2: 15; cf. Ř́íhovský, 1972, 51-53) and a Baumgarten type (Fig. 2: 16; cf. Ř́hovský, 1972, 67-71), and one pin with a small vase head (Fig. 2: 17; cf. Říhovský, 1979, 198-207) were studied. The second site, the Kammerwandgrotte cave, located $7 \mathrm{~km}$ from the Prigglitz mine at Reichenau an der Rax where there is evidence for Early and LBA activities, including metallurgy (Hottwagner and Lang, 1999), was selected. One chisel fragment (Fig. 2:13) and one wire fragment (Fig. 2: 14) from the cave were analysed due to their compositional similarity to the copper produced at Prigglitz-Gasteil. These artefacts cannot be precisely dated by find contexts. In the third site, from the LBA mining region of Prein an der Rax, ca $13 \mathrm{~km}$ from Prigglitz, a double-pointed bronze tool (Fig. 2: 18) was chosen for study. Smelting activities in this region have been dated by 


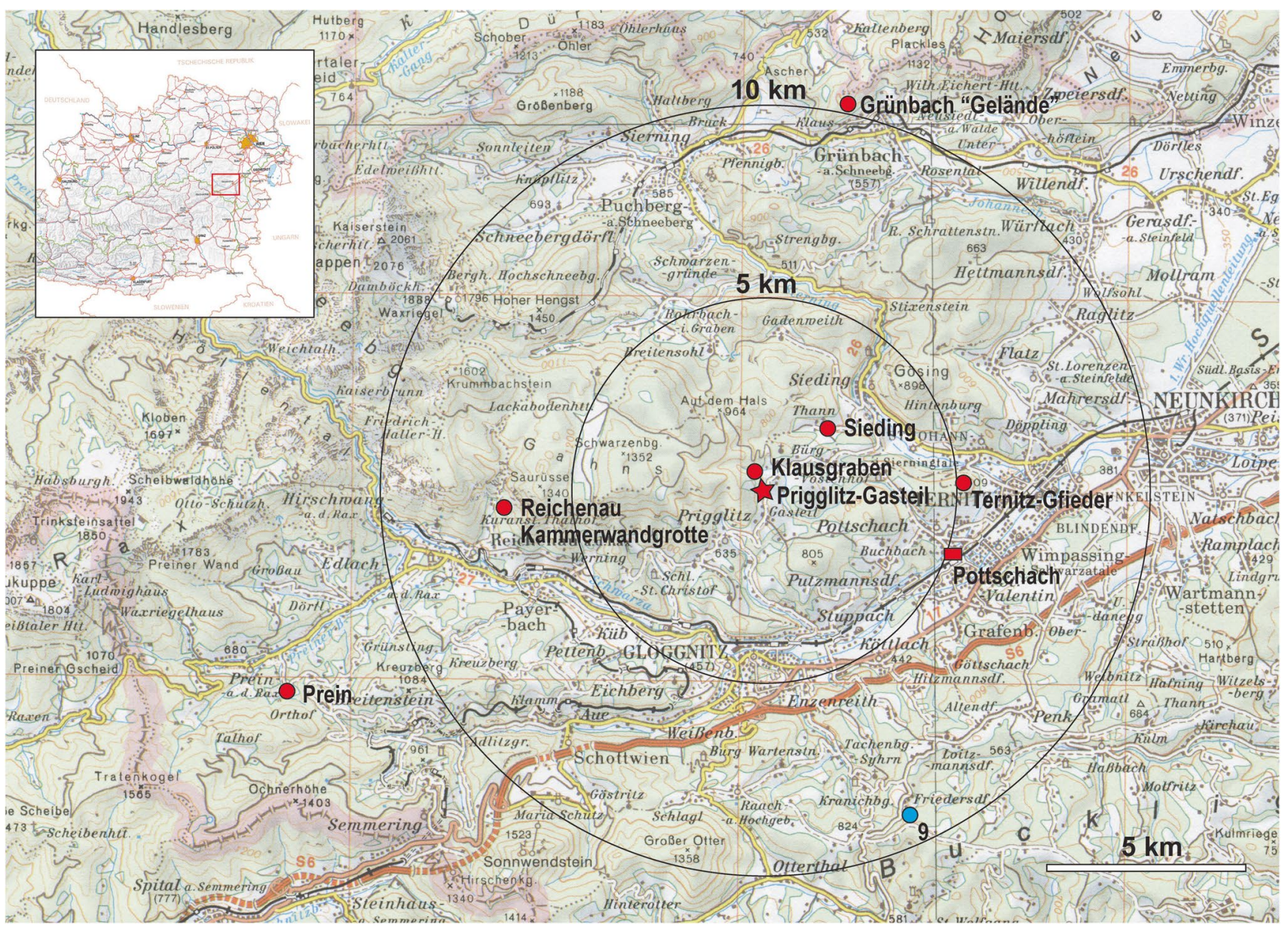

Fig. 1 Location of Prigglitz-Gasteil and the surrounding find spots of the analysed finds in this paper (Cartography: (C) BEV (Bundesamt für Eich- und Vermessungswesen), 2021)

radiocarbon to the Late Urnfield period (ninth century BC; Trebsche, 2015b, 43-47). Fourth, from the metalworking centre likely located at the Gelände near Grünbach hillfort in Schneeberg, one end-winged Haidach type axe (Mayer, 1977, 152-158; Fig. 2: 12) was selected. It belongs to a hoard dating to phase Ha A (ca 1200 to $1080 \mathrm{BC}$; Trebsche et al., 2019). Fifth, almost all cutting tools (a pickaxe, a chisel, an adze, two winged axes, and three socketed axes) from the Mahrersdorf hoard (Lauermann and Rammer, 2013, pl. 44-47) were sampled. Archaeometallurgical analyses of this hoard have already been published in a separate article (Mödlinger and Trebsche, 2020). And finally, two LBA socketed axes found without context from Sieding (Fig. 2: 19) and at the mountain Gfieder in Ternitz (Fig. 2: 20), respectively, were chosen for comparison to the samples from Prigglitz. The specimen from Ternitz belongs to the type 'mit bogenumrandetem Lappendekor und abgesetzter Klinge' (Mayer, 1977, 198-199), whereas the other has unique decoration and was classified as a special type (Mayer 1977, 204 no. 1175).
In sum, the objects studied in this paper include four axes, four knives, four awls, one casting cake, two belt clips, one chisel, two pieces of jewellery (bracelet, pin), one wire fragment, and a bronze rod/wand (Table 1). X-ray fluorescence and $\mathrm{Pb}$-isotope analyses of ca 125 finds from Prigglitz and the surrounding area, including the objects presented in this paper, are published elsewhere (Mödlinger et al. 2021).

\section{Methodology}

Microstructural characterization of the objects and chemical analyses using energy-dispersive X-ray spectroscopy (EDXS) were performed on freshly polished cross-sections taken at the edges of the blades for axes, chisels, and knives; tip for awls; centre of wires and bracelets; and end of belt clips and pins (Fig. 2). Further, X-ray fluorescence (XRF) chemical and high-resolution multi-collector inductively coupled mass spectrometry (HR-MC-ICP-MS) Pb isotope analyses were later carried out on the same and on freshly polished samples (see Mödlinger et al. 2021). The EDXS 


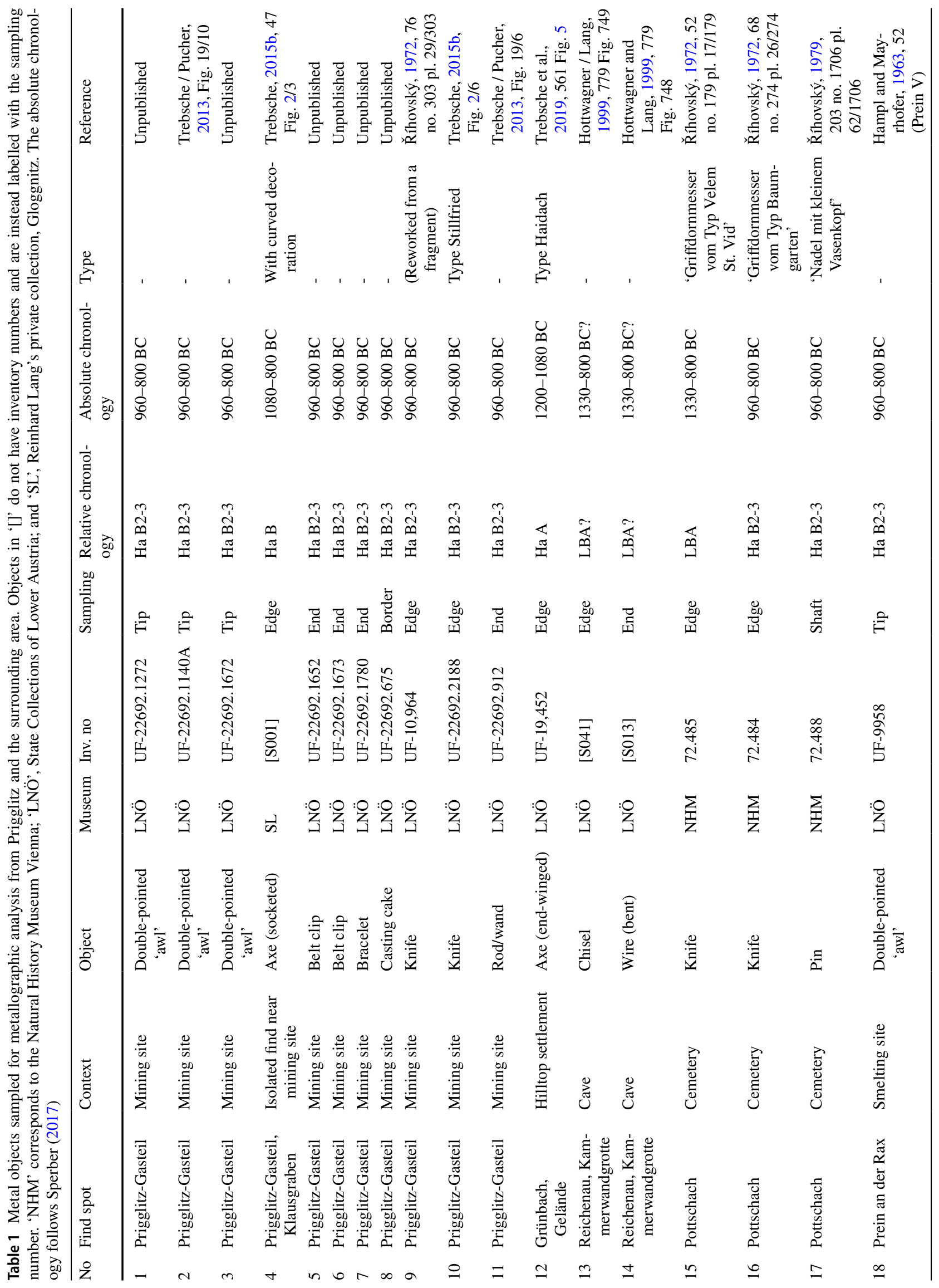


analyses were performed using a JEOL JSM-6460LV SEM with an Oxford Instruments SDD XMax 20 under high vacuum at IRAMAT-CRP2A, Bordeaux, France. The SEM was calibrated using the internally provided software database standards, as well as certified pure $\mathrm{Si}$ and Co standards for quantification. The results shown are the mathematical average of 5-8 spectra of approximately $200 \times 600 \mu \mathrm{m}$ taken for $60 \mathrm{~s}$ each. The presence of minor and trace elements was supported by their detection in higher amount in the corrosion layers. The SEM-EDXS analyses were used to identify different intermetallic compounds, inclusions, and the absence or presence (qualitative) of sulphur (S), which was not detected by XRF. The qualitative presence of each alloying element was classified as major with wt. $\%>1$, minor between 1 and 0.3 , and trace at $<0.3$; their presence was normalized and is given in wt.\% in Table 2.

Chemical analysis was carried out on drilling samples using an ARL Quant'X (Thermo Fisher Scientific) XRF (bulk analyses) at $28 \mathrm{kV}$ (with Pd filter) and $50 \mathrm{kV}$ (with $\mathrm{Cu}$ filter), and on the surfaces of the samples polished for metallographic study using a Fischerscope X-ray XAN 150 (W-band) (point measurements) at $50 \mathrm{kV}$ (Al-filter) using a $1 \mathrm{~mm}$ collimator SD-detector for $50 \mathrm{~s}$. The measuring time/ spot of 1-2 measurements/sample depended on the sample size for both instruments. Each analysis was performed at the CEZA-laboratory in Mannheim, Germany, for the bulk and points, respectively. Quantification of the resultant analyses closely followed the procedure described in Lutz and Pernicka (1996). Manganese, Co, Zn, Se, Cd, Te, and Bi were below the detection limit of the Fischerscope, and, since $\mathrm{S}$ was only measured with EDXS, the results shown in Table 2 should be considered qualitative. There are notable differences between the ARL Quant' $X$ and Fischerscope results (e.g. sample nos. 19a and b), which are due to all-inclusive bulk versus point measurements, the nature of the sample (drilling vs. metallographic cross-section), and the presence of inhomogeneities and corrosion. The error rate for both techniques is $5-10 \%$ for the major elements, and even lower for $\mathrm{Cu}$, and $20-50 \%$ for minor and trace elements.

Characterization of the sample's microstructure was performed on prepared cross-sections. Each sample was mounted in cold acrylic resin and polished using 400-1200 SiC papers, followed by a diamond suspension paste of up to $0.25 \mu \mathrm{m}$ granulometry. The samples were characterized using optical microscopy in both bright and dark fields, chemically analysed using EDXS, and then etched for metallographic examination using aqueous ferric chloride and Klemm II to show greater detail. While aqueous ferric chloride produces a grain contrast, Klemm II is a colour etchant, which colours grains depending on their orientation; segregation also becomes visible and intermetallics are not etched. The total amount of deformation applied to each sample was calculated by measuring the shape factor (SF) of the CuS or CuFeS inclusions (see Mödlinger and 
Fig. 2 Late Bronze Age objects from southeastern Lower Austria. Numbers 1-3 and 5-11 are from Prigglitz-Gasteil; 4 from Prigglitz-Gasteil, Klausgraben; 12 Grünbach, Gelände; 13-14 Reichenau, Kammerwandgrotte; 15-17 Pottschach; 18 Prein an der Rax; 19 Sieding; and 20 Ternitz, Gfieder The drawings; nos. 1-3, 5-8, 10-12, 18 were done by Daniela Fehlmann and Ulrike Weinberger; 4, 13-14, 20 by Franz Drost; 9, 15-17, 19 are from unknown artist(s). The numbers correspond to those listed in Tables 1, 2, and 3

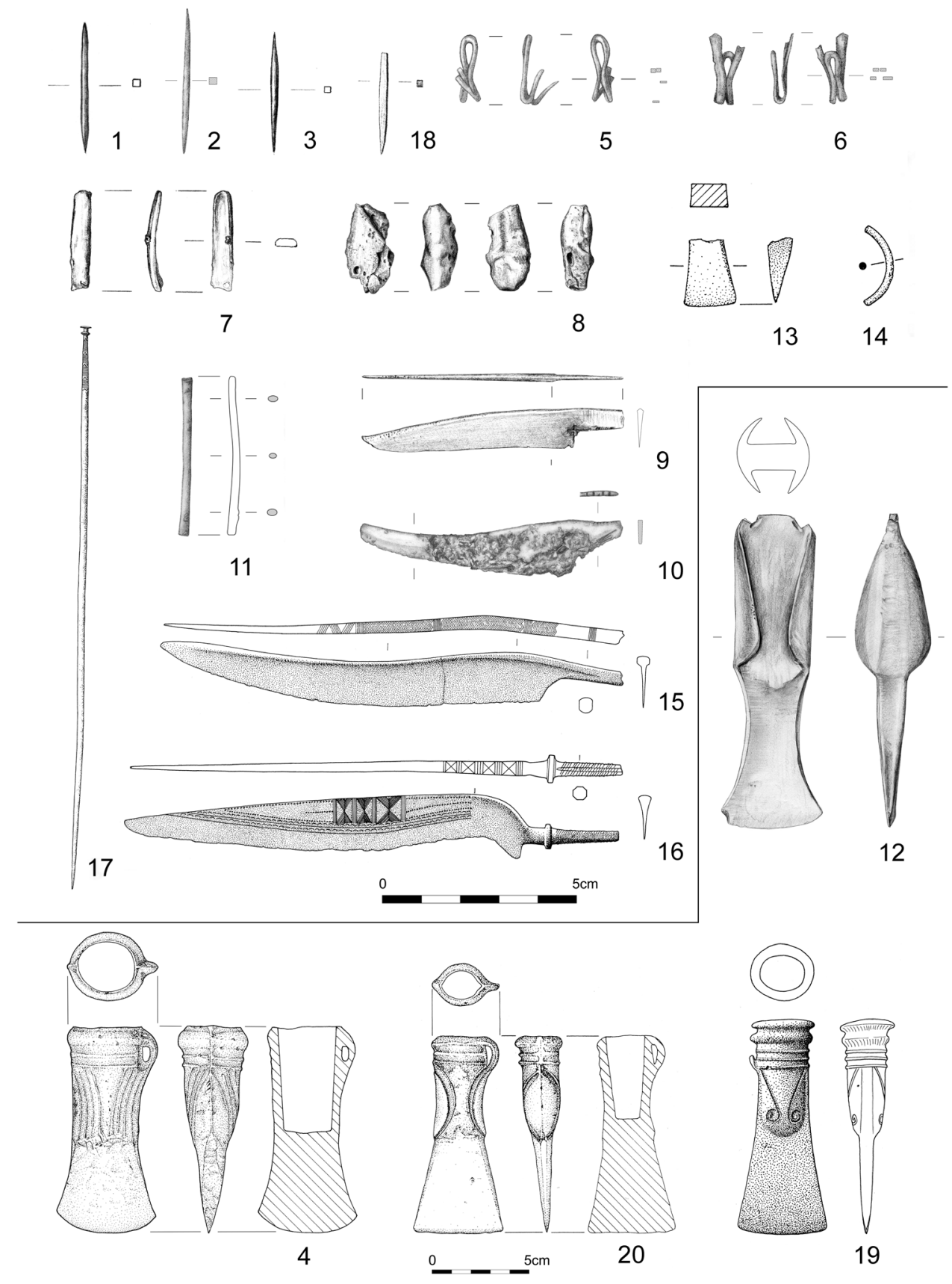

Piccardo 2013). Vickers hardness measurements were carried out using a Leitz Durimet $72-1 \mathrm{~b}$ instrument at $100 \mathrm{~g}$ load over 10 s. An FT-9929195 test block from Future-Tech-Corporation was used as a standard.

\section{Results}

In the following, the results are focused on the metallographic analyses. The chemical analyses are thoroughly discussed elsewhere (Mödlinger et al. 2021). However, the chemical compositions of the finds discussed in this paper are provided in Table 2 .

\section{Axes and chisel}

\section{Prigglitz-Gasteil, ID S001, socketed axe}

A sample was taken on the edge of the axe's blade. Analysis of the sample showed $8.5 \mathrm{wt} . \% \mathrm{Sn}$ and $0.6 \% \mathrm{~S}$. Nickel was also present at about $0.1 \%$ with $\mathrm{Fe}, \mathrm{As}, \mathrm{Sb}, \mathrm{Ag}$, and $\mathrm{Pb}$ in trace amounts. The unetched sample shows $\mathrm{CuS}-$ inclusions with about $60-70 \%$ deformation. Etching with 
Table 2 The elemental percentages of each sample are given in wt.\%. Manganese, $\mathrm{Co}, \mathrm{Zn}, \mathrm{Se}, \mathrm{Cd}, \mathrm{Te}$, and $\mathrm{Bi}$ were not detected in the samples analysed with the Fischerscope (FS). All other samples show $\leq 0.005 \mathrm{Mn}, \mathrm{Se}$, and $\mathrm{Te}, 0.01 \mathrm{Co},<0.1 \mathrm{Zn},<0.01 \mathrm{Cd}$, and $<0.06 \mathrm{Bi}$. Use of the Fischerscope is indicated by FS. An aster- isque (*) indicates drilling samples analysed by ARL Quant'X XRF. Noteworthy are the differing amounts of $\mathrm{Sn}$ in the socketed axe from Sieding that appear with different analytical methods (see 'Sieding, inv. no. UF-5098, socketed axe')

\begin{tabular}{|c|c|c|c|c|c|c|c|c|c|c|c|c|}
\hline No & Site & Object & Inv.no & $\mathrm{Cu}$ & $\mathrm{Fe}$ & $\mathrm{Ni}$ & As & $\mathrm{Ag}$ & $\mathrm{Sn}$ & $\mathrm{Sb}$ & $\mathrm{Pb}$ & FS \\
\hline 1 & Prigglitz-Gasteil & Double-pointed 'awl' & UF-22692.1272 & 89 & n.d & n.d & n.d & n.d & 11.0 & n.d & n.d & $\mathrm{x}$ \\
\hline 2 & Prigglitz-Gasteil & Double-pointed 'awl' & UF-22692.1140A & 90 & n.d & n.d & n.d & n.d & 9.5 & 0.12 & n.d & $\mathrm{x}$ \\
\hline 3 & Prigglitz-Gasteil & Double-pointed 'awl' & UF-22692.1672 & 86 & n.d & 0.07 & n.d & n.d & 13.7 & 0.10 & 0.08 & $\mathrm{x}$ \\
\hline 4 & $\begin{array}{l}\text { Prigglitz-Gasteil, } \\
\text { Klausgraben }\end{array}$ & Axe (socketed) & {$[\mathrm{S} 001]^{*}$} & 91 & $<0.05$ & 0.12 & 0.021 & 0.008 & 8.5 & 0.092 & 0.011 & \\
\hline 5 & Prigglitz-Gasteil & Belt clip & UF-22692.1652 & 91 & 0.22 & 0.07 & 0.03 & n.d & 8.3 & 0.24 & n.d & $\mathrm{x}$ \\
\hline 6 & Prigglitz-Gasteil & Belt clip & UF-22692.1673 & 88 & 0.06 & 0.28 & 0.32 & 0.28 & 10.3 & 0.37 & 0.34 & $\mathrm{x}$ \\
\hline 7 & Prigglitz-Gasteil & Bracelet & UF-22692.1780 & 87 & 0.13 & 0.04 & n.d & n.d & 12.8 & 0.13 & n.d & $\mathrm{x}$ \\
\hline 8 & Prigglitz-Gasteil & Casting cake & UF-22692.675* & 100 & 0.11 & 0.06 & 0.012 & 0.010 & 0.017 & 0.095 & 0.012 & \\
\hline 9 & Prigglitz-Gasteil & Knife & UF-10,964 & 84 & 0.73 & 0.05 & n.d & n.d & 15.3 & n.d & 0.14 & $\mathrm{x}$ \\
\hline 10 & Prigglitz-Gasteil & Knife & UF-22692.2188 & 89 & 0.19 & 0.14 & 0.14 & n.d & 9.9 & 0.41 & n.d & $\mathrm{x}$ \\
\hline 11 & Prigglitz-Gasteil & Rod / wand & UF-22692.912 & 87 & n.d & 0.03 & n.d & n.d & 11.9 & 0.06 & 0.61 & $\mathrm{x}$ \\
\hline 12 & Grünbach, Gelände & Axe (end-winged) & UF-19,452 & 89 & 0.09 & 0.40 & 0.51 & 0.15 & 9.1 & 0.52 & 0.19 & $\mathrm{x}$ \\
\hline 13 & $\begin{array}{l}\text { Reichenau, Kam- } \\
\text { merwandgrotte }\end{array}$ & Chisel & [S041] & 91 & n.d & 0.15 & 0.19 & 0.08 & 7.5 & 0.25 & 0.39 & $\mathrm{x}$ \\
\hline 14 & $\begin{array}{l}\text { Reichenau, Kam- } \\
\text { merwandgrotte }\end{array}$ & Wire (bent) & [S013] & 88 & 0.14 & 0.06 & 0.06 & n.d & 12.0 & 0.20 & 0.05 & $\mathrm{x}$ \\
\hline 15 & Pottschach & Knife & $72,485 *$ & 89 & 0.36 & 0.06 & 0.132 & 0.087 & 9.2 & 1.24 & 0.019 & \\
\hline 16 & Pottschach & Knife & $72,484 *$ & 89 & 0.05 & 0.07 & 0.021 & 0.016 & 10.6 & 0.214 & 0.020 & \\
\hline 17 & Pottschach & Pin & $72,488^{*}$ & 90 & 0.10 & 0.07 & 0.015 & 0.020 & 9.2 & 0.130 & 0.007 & \\
\hline 18 & Prein an der Rax & Double-pointed 'awl' & UF-9958 & 94 & 0.08 & 0.05 & n.d & n.d & 5.2 & 0.10 & 0.69 & $\mathrm{x}$ \\
\hline $19 \mathrm{a}$ & Sieding & Axe (socketed) & UF-5089 [S022]* & 92 & 0.11 & 0.13 & 0.051 & 0.011 & 7.7 & 0.095 & 0.102 & \\
\hline $19 b$ & Sieding & Axe (socketed) & UF-5089 [S039] & 89 & 0.11 & 0.11 & 0.06 & n.d & 10.3 & 0.14 & 0.09 & $\mathrm{x}$ \\
\hline 20 & Ternitz, Gfieder & Axe (socketed) & {$[\mathrm{S} 003]^{*}$} & 91 & 0.16 & 0.06 & 0.01 & 0.005 & 8.7 & 0.02 & 0.005 & \\
\hline
\end{tabular}

ferric chloride reveals coring (zones with 9 to $15 \%$ Sn are clearly distinguishable) and small, equiaxed polyhedric grains. The grains are deformed and show strain lines and annealing twins. In the matrix, $(\alpha+\delta)$ eutectoid is present; due to its brittleness and the applied deformation, there are many cracks (Fig. 3a). Their presence in the axe indicates that annealing took place at relatively low temperatures (i.e. $<520{ }^{\circ} \mathrm{C}$ ), which counterintuitively still permitted the formation of new grains. Corrosion in the sample mainly consists of copper oxide inclusions (cuprite) and copper carbonates. There are also corrosion layers of tin oxides on the object's surface, which are typical for bronze. Hardness measurements give up to $297 \mathrm{HV}$ values in tin-richer zones and $245 \mathrm{HV}$ in zones with less tin. In the more homogenous zone at the very edge, hardness reaches $254 \mathrm{HV}$, while the sample's core is between 206 and $245 \mathrm{HV}$.

\section{Grünbach am Schneeberg, inv. no. UF-19.452, median-winged axe}

The median-winged axe-type Freudenberg from Grünbach am Schneeberg was sampled on the edge and found to contain $9 \% \mathrm{Sn}, 0.5 \%$ of As and $\mathrm{Sb}$ each, as well as $0.1 \%$ $\mathrm{Ag}, 0.4 \% \mathrm{Ni}$, and $0.2 \% \mathrm{~Pb}$. Iron is present in traces. The unetched sample shows ca 30-40\% deformed, light grey CuS-inclusions. Etching with ferric chloride reveals coring (indicating a non-complete homogenization) as well as slightly deformed polyhedric grains with twins and strain lines. Some eutectoid is present. Corrosion can be found inter- and intracrystalline. On the edge of the sample, corrosion follows the dendritic structure. Also, bacterial-induced corrosion was noted (see Piccardo et al., 2013) (Fig. 3b). Copper oxide (mainly cuprite) and copper carbonate layers cover the surface of the sample. Hardness measurements give about 151-221 HV values, with a harder edge than in the sample's core. 
Fig. 3 Microstructures. Axe ID S001 from Prigglitz-Gasteil: a SEM image showing coring, CuS-inclusions (dark grey), and broken $(\alpha+\delta)$ eutectoid (light grey). Winged axe inv. no. UF-19.452 from Grünbach: b Unetched, in polarized light. Bacterial induced corrosion is visible. Chisel ID S041 from Kammerwandgrotte: c Unetched. Coring is visible as massively elongated $\mathrm{CuS}$-inclusions. The corrosion follows the microstructural features inter- and intracrystallinearly. Socketed axe ID S042 from Ternitz: d Unetched. Coring is visible. At the centre, one can see $(\alpha+\delta)$ eutectoid (light grey) with surrounding interand intracrystalline corrosion, under which are cuprite (dark grey, below the eutectoid) and a copper inclusion. The CuFeSinclusions (dark grey) are not significantly deformed. e Etched with ferric chloride. Note the deformed grains of $\alpha$-solid solution with deformed twins and strain lines. Socketed axe inv.no. UF-5098 from Sieding: f Etched with ferric chloride. Note the deformed grains of $\alpha$-solid solution with deformed twins and strain lines
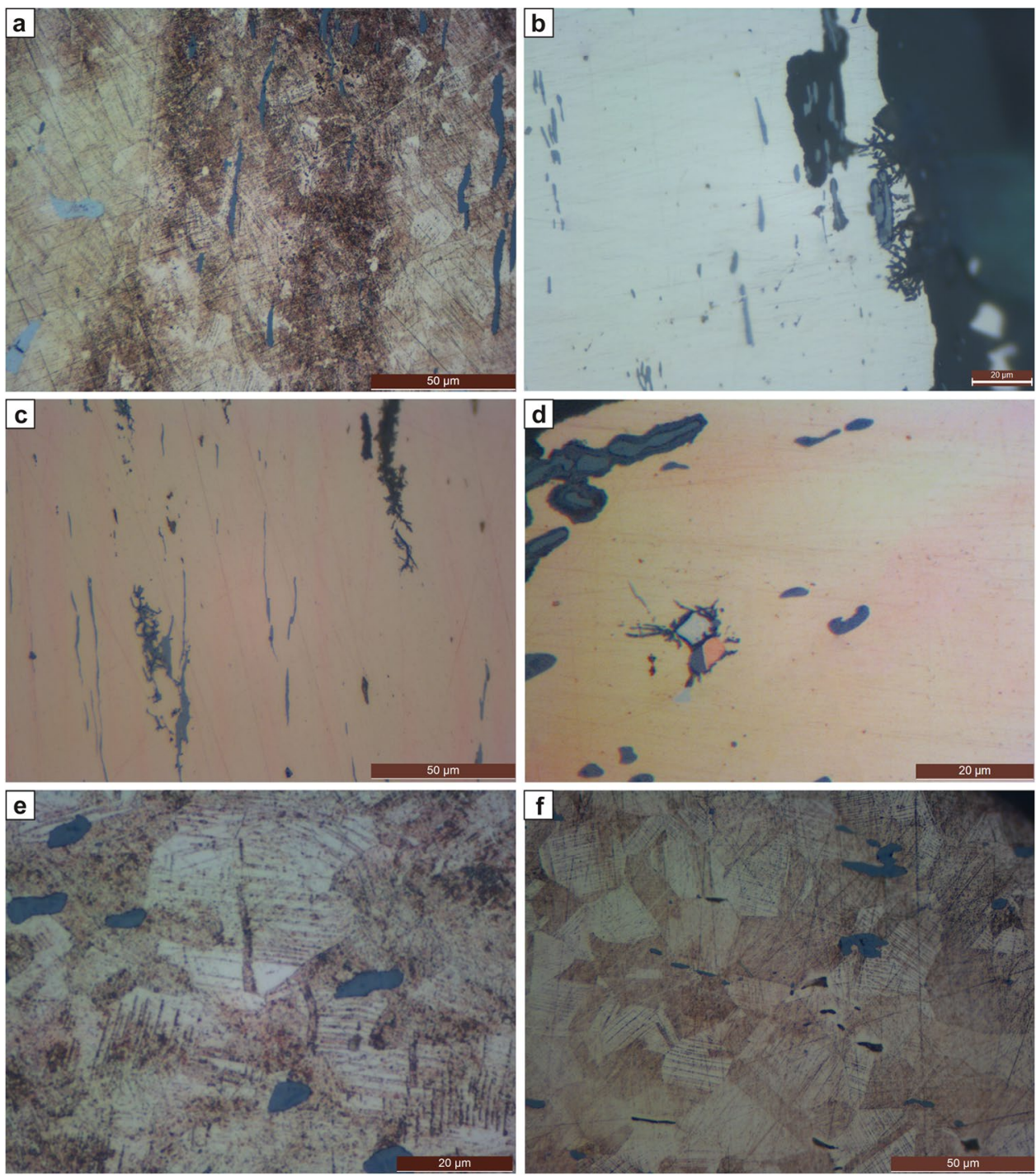

\section{Kammerwandgrotte, ID S041, chisel}

The chisel was sampled on its edge and found to contain 7.1-8\% Sn (depending on the analytical method used), $0.2 \%$ As, $0.1 \% \mathrm{Ni}, 0.2 \% \mathrm{Sb}, 0.4 \% \mathrm{~Pb}$, and some $\mathrm{S}$. The $\mathrm{S}$ was under the detection limit of the EDXS for bulk analyses but was detected in the $\mathrm{CuS}$-inclusions. Iron and $\mathrm{Ag}$ are present in traces, and the unetched sample shows ca $90 \%$ deformed light grey CuS- and globular Pb-inclusions (Fig. 3c). Etching with ferric chloride revealed slight coring, indicating incomplete homogenization, and fine, slightly deformed, polyhedric grains with strain lines and twins. There is also $(\alpha+\delta)$ eutectic, and corrosion is present both inter- and intracrystallinearly. Copper oxide crystals (cuprite; dark red in polarized light) and alternating copper oxides and carbonate layers cover the surface of the sample. Tin oxides are present, as are $\mathrm{P}, \mathrm{Si}$, and $\mathrm{Ca}$, which derive from the soil.
Hardness measurements give about 202-237 HV values, with a harder edge than in the core of the sample.

\section{Ternitz (Gfieder), ID S042, socketed axe}

The socketed axe was sampled on its edge and found to contain $10.8 \%$ Sn using EDXS and $8.7 \%$ with XRF, and $0.7 \% \mathrm{~S}$ and about $0.16 \% \mathrm{Fe}$. Sulphur and Fe are mainly present in the $\mathrm{CuFeS}$-inclusions. Nickel, As, $\mathrm{Ag}, \mathrm{Sb}$, and $\mathrm{Pb}$ are present in trace amounts. The unetched sample shows slightly deformed $\mathrm{CuFeS}$-inclusions, which indicate a total deformation of about $10-20 \%$ in the sampled area (Fig. 3d). Etching the sample with ferric chloride revealed an inhomogeneous microstructure - tin-rich areas contain up to $15 \% \mathrm{Sn}$, tin poor areas up to $6 \%$ and severely deformed equiaxed grains of $\alpha$-solid solution (Fig. 3e). The grains show deformed annealing twins as well as strain lines, and $(\alpha+\delta)$ eutectoid is present. The 
deformation and presence of eutectoid indicate annealing at low temperature $\left(<520^{\circ} \mathrm{C}\right)$ or short annealing at higher temperatures with a final heavy deformation. Some copper drops are also visible in the matrix, and the corrosion follows both the original dendritic structure and, in small areas, the grain boundaries and the intracrystalline structures of the $\alpha$-solid solution equiaxed grains. Both copper oxides (cuprite) and copper carbonates (mainly azurite and malachite) are visible in polarized light, as is cuprite as inclusions. The hardness values are 206-242 HV on the very edge and slightly lower (193-221 HV) $3 \mathrm{~mm}$ inward, corresponding to high final deformation.

\section{Sieding, inv. no. UF-5098, socketed axe}

The socketed axe was sampled on its edge and contained 7.7-11.4\% Sn, $0.5 \% \mathrm{~S}$, and about $0.1 \% \mathrm{Fe}, \mathrm{Ni}, \mathrm{Sb}$, and $\mathrm{Pb}$. Sulphur and $\mathrm{Fe}$ are mainly present in the $\mathrm{CuFeS}$-inclusions, and $\mathrm{As}$ and $\mathrm{Ag}$ are in trace amounts. The Sn composition varied by sample type, with XRF of the drilling samples showing $7.7 \%$ and surface analyses of the metallographic sample at about $10.3 \%$, similar to the $11.4 \%$ result from the EDXS. The unetched sample shows slightly deformed $\mathrm{CuFeS}$-inclusions, which indicate a total deformation of about 10-20\%. Lead is present in small inclusions. Etching the sample with ferric chloride revealed coring and a very fine grain structure (grain sizes smaller than 10, according to ASTM) (Fig. 3f). The equiaxed grains of $\alpha$-solid solution showed twins and strain lines. While the grains show slight deformation on the very edge, they are slightly more deformed in the sample's core. The corrosion follows the inter- and intracrystalline structures of the grains. Calcium, $\mathrm{Cl}, \mathrm{Si}$, and tin oxides were present in the corrosion, with the former three deriving from the surrounding burial soil. The most significant part of the corrosion is copper oxides (cuprite) and carbonates of mainly azurite and malachite. The hardness values of 213-216 HV in the sample's core are higher than on the very edge (166-170 HV). These hardness values also correspond with the more deformed grains in the sample's core.

\section{Knives}

\section{Pottschach, inv. no. 72.484, knife}

The knife was sampled on its edge and found to contain $11 \% \mathrm{Sn}, 0.2 \% \mathrm{Sb}$, and $0.4 \% \mathrm{~S}$. Sulphur and small amounts of $\mathrm{Fe}$ are mainly present in $\mathrm{CuFeS}$-inclusions. Iron, $\mathrm{Ni}, \mathrm{As}$, $\mathrm{Ag}$, and $\mathrm{Pb}$ are present in trace amounts. The sample was taken from the centre of the blade's edge. The unetched sample shows elongated $\mathrm{CuFeS}$-inclusions, indicating a total deformation of 30-40\% at the very edge and about 10-20\% towards the core in the sample. Etching the sample with ferric chloride revealed equiaxed grains of $\alpha$-solid solution with twins (Fig. 4a). Only at the very edge, congruent with the significantly more deformed $\mathrm{CuFeS}$-inclusions in this area did the grains show deformation and show strain lines with slight coring.

As the final working step, the edge of the chisel was cold deformed. The corrosion follows both the deformed $\alpha$-solid solution equiaxed grains' grain boundaries and the intragranular annealing twins. Under polarized light, the sample showed both copper oxides (cuprite) and carbonates (mainly azurite and malachite). The hardness values of 206-228 HV on the very edge correspond with microstructural observations (higher levels of total deformation of CuFeS-inclusions and grain deformation and strain lines) and the relatively high amount of Sn. The core of the sample dissimilarly showed 132-151 HV.

\section{Pottschach, inv. no. 72.485 , knife}

The knife was sampled on its edge and found to be a tinantimony bronze containing mean values of $9 \% \mathrm{Sn}, 1.2 \% \mathrm{Sb}$, $0.1 \% \mathrm{As}, 0.7 \% \mathrm{~S}$, and $0.4 \% \mathrm{Fe}$. Sulphur and Fe are mainly present in $\mathrm{CuFeS}$-inclusions, and $\mathrm{Ni}, \mathrm{Ag}$, and $\mathrm{Pb}$ are present in trace amounts. The sample was taken from the edge at the centre of the blade. The unetched sample shows slightly elongated $\mathrm{CuFeS}$-inclusions, which indicate a total amount of deformation of $20-30 \%$ at the very edge in the sampled area, and about 10-20\% in the core. Etching the sample with ferric chloride revealed heavy coring and large equiaxed grains (ca 30-60 $\mu \mathrm{m}$ in diameter) of $\alpha$-solid solution with twins (Fig. 4c). As the final working step, the knife's edge was annealed. Some copper drops are visible in the matrix (Fig. 4b). The corrosion follows the grain boundaries of the $\alpha$-solid solution equiaxed grains. According to their colour under polarized light, copper carbonates (mainly azurite and malachite) are the main corrosion products. The hardness values of 128-143 HV confirm the microstructural observations; though the edge received a higher amount of total deformation, the annealing following the cold deformation resulted in an equally low hardness throughout the sample.

\section{Prigglitz, inv. no. 10.964, knife}

X-ray fluorescence analyses could not be carried out with accuracy due to the presence of corrosion; however, it is worth pointing out that traces of $\mathrm{Ni}$ and $\mathrm{Pb}$ were detected. The following compositional percentages derive from the SEM-EDXS analyses carried out on the polished metallographic sample's surface. The knife was formed from a tin-bronze containing mean values of $13.5 \% \mathrm{Sn}$ and $0.6 \%$ $\mathrm{S}$ that were mainly present in $\mathrm{CuFeS}$-inclusions. The sample was taken from the centre of the blade. The unetched sample shows elongated $\mathrm{CuFeS}$-inclusions, which indicate a 
Fig. 4 Microstructures. Knife inv.no. 72.484 from Pottschach: a Etched with ferric chloride. Note the elongated CuFeSinclusions and the deformed grains of $\alpha$-solid solution with deformed twins and strain lines. b Knife inv.no. 72.485 from Pottschach: b Unetched. Note the copper drops in the matrix, surrounded by corrosion. c Etched with ferric chloride. Knife inv.no. 10.964 from Prigglitz: d Etched with ferric chloride. Note the slightly deformed twins and strain lines of the polyhedric grains of $\alpha$-solid solution. Also, the $(\alpha+\delta)$ eutectoid is present. Knife inv. no. UF-22692.2188 (22.692) from Prigglitz: e Unetched. Slight coring is visible. $\mathbf{f}$ Etched with ferric chloride. Note the deformed polyhedric grains of $\alpha$-solid solution with twins and strain lines
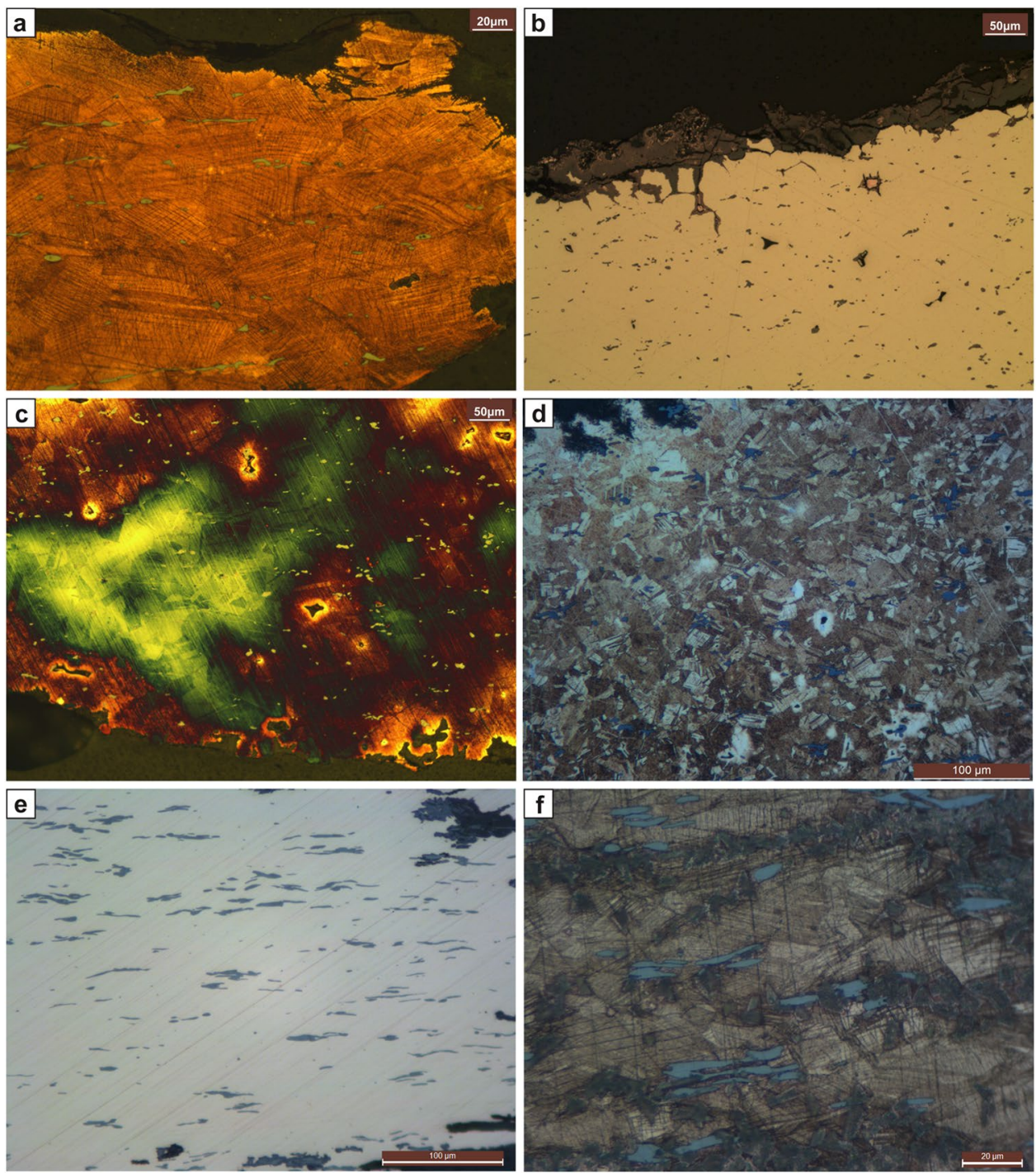

total amount of deformation of 60-70\% at the very edge and about 10-20\% towards the core. Etching the sample with ferric chloride revealed coring and very fine polyhedric grains of $\alpha$-solid solution with twins and strain lines (Fig. 4d). The grains are severely deformed along the edge, and $(\alpha+\delta)$ eutectoid is present, indicating low temperature $\left(<520{ }^{\circ} \mathrm{C}\right)$ or shorter annealing at higher temperatures took place. The applied deformation did not result in a broken eutectoid. The SEM images showed tiny, globular $\mathrm{Pb}$-inclusions throughout the matrix. Corrosion in the sample follows intracrystalline structures to a smaller degree, the dendritic features. Elements such as $\mathrm{Al}, \mathrm{Si}$, and $\mathrm{P}$ were present and derived from the soil. Apart from the copper oxides and carbonates, tin oxides are also present. The hardness values of 245-254 HV on the very edge and 181-199 in the sample's core confirm the microstructural observations.

\section{Prigglitz, inv. no. UF-22692.2188 (22.692), knife}

X-ray fluorescence analyses of this sample should be considered qualitative, as some corrosion was present. The knife was formed from tin-bronze containing mean values of $10 \%$ Sn with about $0.4 \% \mathrm{Sb}, 0.2 \% \mathrm{Fe}$, and $0.1 \% \mathrm{Ni}$ and As. The $\mathrm{S}$ and $\mathrm{Fe}$ are present in $\mathrm{CuFeS}$-inclusions. The sample was taken from the blade. The unetched sample shows slightly elongated $\mathrm{CuFeS}$-inclusions, which indicate a total amount of deformation of 30-40\%. Etching the sample with ferric chloride revealed coring and significantly deformed polyhedric grains of $\alpha$-solid solution with twins and strain lines (Fig. 4e-f). As the final working step, the edge of the knife was cold deformed. The corrosion follows both the previous as-cast structure (dendrites) as well as the grain boundaries of the $\alpha$-solid solution equiaxed grains. According to their colour under polarized light, copper carbonates (mainly azurite and malachite) are the main corrosion products. 
The hardness values of 193-274 HV, with $274 \mathrm{HV}$ on the very edge, make this the highest hardness value of the four knives.

\section{Awls}

\section{Prigglitz, inv. no. UF-22692.1140A, awl}

The awl is made of tin-bronze containing mean values of $9.5 \% \mathrm{Sn}, 0.1 \% \mathrm{Sb}$, and $0.7 \% \mathrm{~S}$, which is mainly present in CuS-inclusions. The tip of the awl was sampled longitudinally and transversally (cross-section). The unetched longitudinal sample showed slightly elongated CuS-inclusions, indicating a total amount deformation of $20-30 \%$, while the cross-section only shows light deformation at a maximum of $15 \%$. The $(\alpha+\delta)$ eutectoid of the $\mathrm{Cu}-\mathrm{Sn}$ system is visible in the unetched sample, and once etched with ferric chloride coring and fine, deformed equiaxed grains of $\alpha$-solid solution with twins and strain lines were visible (Fig. 5a). The presence of $(\alpha+\delta)$ eutectoid indicates short, low-temperature annealing, followed by cold deformation. As the final working step, the tip of the awl was cold deformed. Corrosion in the sample follows the grain boundaries of the $\alpha$-solid solution equiaxed grains, and it expands intracrystallinearly. According to their colour under polarized light and the EDXS analyses, copper carbonates (mainly azurite and malachite) are the main corrosion products on the awl's surface, while copper (mainly cuprite) and tin oxides are visible in the inter- and intracrystallinearly. The hardness values of 193-228 HV are relatively high for a $9.5 \%$ tin-bronze and correspond with the deformation applied in the final working step.
Fig. 5 Microstructures. Awl inv.no. UF-22692.1140A from Prigglitz: a Etched with Klemm II. Note coring and $(\alpha+\delta)$ eutectoid. Awl inv.no. 1272 from Prigglitz: b Etched with ferric chloride. The CuS-inclusions are elongated. Awl inv.no. UF-22692.1672from Prigglitz: c Etched with ferric chloride. Note the elongated CuSinclusions. Awl inv.no. UF-9958 from Prein: d Unetched. Note the corrosion, outlining the microstructural features. Casting cake inv. no. UF-22692.675 from Prigglitz. e Unetched. Note the many $\mathrm{CuS}$-inclusions and, in the centre, some CuSbinclusions in the SEM image. White inclusions are rich in $\mathrm{Sb}$ (ca 35\%) as well as Ag and As (below 1\%). Belt clip inv.no. UF-22692.1673 from Prigglitz: f Etched with Klemm II. Heavy coring is visible
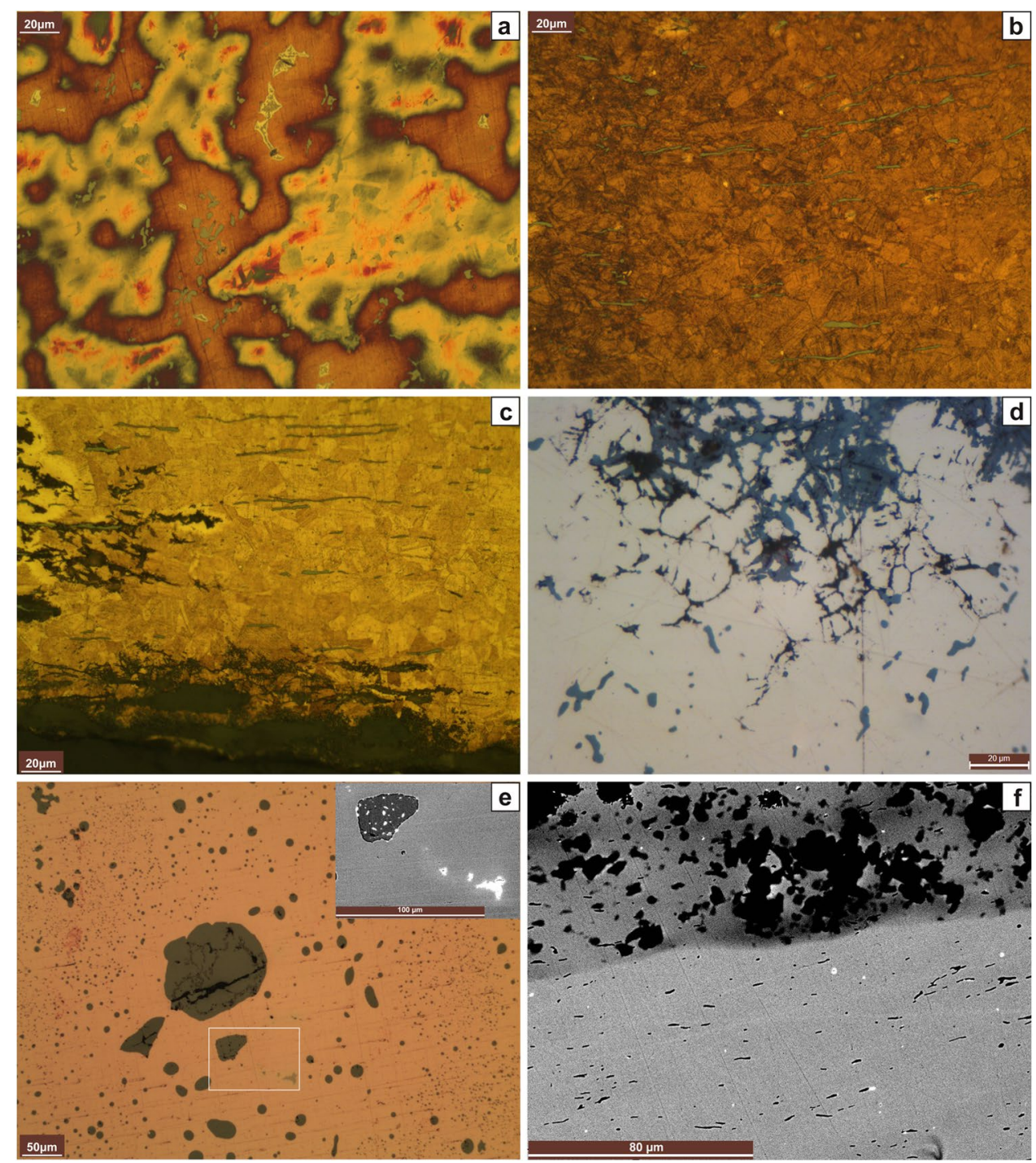


\section{Prigglitz, inv. no. UF-22692.1272, awl}

The awl was formed from tin-bronze containing mean values of $11 \% \mathrm{Sn}$ and $0.3 \% \mathrm{~S}$, which was mainly present in CuSinclusions. The tip of the awl was sampled longitudinally, and unetched showed slightly elongated $\mathrm{CuS}$-inclusions, indicating a total amount of deformation of 40-50\%. After etching with Klemm II heavy coring was revealed, indicating an inhomogeneous alloy (Fig. 5b). Both Klemm II and ferric chloride etched surfaces showed small, slightly deformed equiaxed grains of $\alpha$-solid solution with twins as well as strain lines. No $(\alpha+\delta)$ eutectoid of the $\mathrm{Cu}-\mathrm{Sn}$ system was visible, indicating that the awl underwent longer, or more frequent annealing followed by cold deformation. In the final working step, the tip of the awl was cold worked. The corrosion follows the dendritic structure. According to the corrosion colours under polarized light, copper carbonates (mainly azurite and malachite) are the main products on the awl's surface. No inter- or intracrystalline corrosion was noted. The hardness values of 187-206 HV are relatively high for a $10 \%$ tin-bronze and correspond with the deformation applied in the final working step.

\section{Prigglitz, inv. no. UF-22692.1672, awl}

The awl was formed from tin-bronze containing mean values of $14 \% \mathrm{Sn}, 0.1 \% \mathrm{Sb}$, and $0.5 \% \mathrm{~S}$, which was mainly present in $\mathrm{CuS}$-inclusions with low amounts of $\mathrm{Ni}$. Nickel and $\mathrm{Pb}$ are present in trace amounts. The tip of the awl was sampled longitudinally, and unetched showed severely elongated $\mathrm{CuS}$-inclusions, indicating a total amount of deformation of $70-80 \%$ (Fig. 5c). After etching the sample with Klemm II and ferric chloride, light coring was revealed, indicating an almost homogenous alloy. Both Klemm II and ferric chloride developed small, slightly deformed equiaxed grains of $\alpha$-solid solution with twins and strain lines. No $(\alpha+\delta)$ eutectoid of the $\mathrm{Cu}-\mathrm{Sn}$ system remained, indicating more prolonged or more frequent annealing followed by cold deformation. In the final working step, the tip of the awl was cold worked. Half of the sample is massively corroded. The corrosion follows the grain boundaries and, intra-granularly, along the dislocations of single grains (both twins and strain lines). According to the corrosion colours under polarized light, copper carbonates (mainly azurite and malachite) are the main corrosion products on the awl's surface. Within the corrosion, there was also $\mathrm{SnO}$ that was measured by EDXS. Copper oxides (cuprite) can be found in the centre of the sample. The hardness values of 245-274 HV for the sample are the highest measured in this study. They are related to both the high amount of Sn in the alloy and the intense cold deformation applied in the final step of production.
Prein, inv. no. UF-9958, awl

The awl is tin-bronze and contains mean values of $5 \% \mathrm{Sn}$ and $0.7 \% \mathrm{~Pb}$. Sulphur is mainly present in the CuFeS-inclusions, and $\mathrm{Fe}$ in trace amounts. The sample was cut transversally from a fragment of the awl. Unetched, the sample shows slightly elongated $\mathrm{CuFeS}$-inclusions, indicating a total amount of deformation of $0-20 \%$, which is not surprising for the cut. The total amount of longitudinal deformation could not be measured. Etching the sample with ferric chloride revealed coring and small, deformed equiaxed grains of $\alpha$-solid solution with twins and strain lines. The corrosion follows the grain boundaries of the $\alpha$-solid solution equiaxed grains and also expands intracrystallinearly (Fig. 5d). According to the sample's colour under polarized light, copper carbonates (mainly azurite and malachite) are the main corrosion products on the awl's surface, while copper (mainly cuprite) and tin oxides are visible inter- and intracrystallinearly. The low hardness values of 160-181 HV correspond with the alloy composition.

\section{Other objects}

\section{Prigglitz, inv. no. UF-22692.675, casting cake}

The casting cake consists of rather pure copper with only $1.7 \% \mathrm{~S}, 0.1 \% \mathrm{Fe}$, and small amounts of $\mathrm{Sb}(0.1 \%)$. Other elements, such as $\mathrm{Ni}, \mathrm{Ag}, \mathrm{As}$, and $\mathrm{Pb}$, are present in trace amounts. The highly porous as-cast shows a homogenous copper matrix without any coring or dendrites. No cuprite was noted under polarized light; however, $\mathrm{CuO}$ - mainly carbonates - is present in the corrosion and on the casting cake's surface. Globular, black CuS-inclusions - some of them containing up to $2 \% \mathrm{O}$ and/or up to $1 \% \mathrm{Sb}$ - are distributed in various sizes all over the sample's surface. There are small, white inclusions that mainly contain $\mathrm{Sb}$ (35\%) and Ag and As below 1\% (Fig. 5e). Hardness values are around 96-105 HV.

\section{Prigglitz, inv. no. UF-22692.1673, belt clip}

The belt clip is made of tin-bronze with about $7.5 \% \mathrm{Sn}$, $0.7 \% \mathrm{Sb}$, and $0.2 \% \mathrm{~S}$. The XRF sample contained corrosion, so preference should be given to the SEM-EDXS chemical data; however, it is important to note that with XRF, $0.3 \% \mathrm{Ni}, \mathrm{As}, \mathrm{Ag}$, and $\mathrm{Pb}$ were detected. One end of the belt clip was pinched off, and the cross-section of the belt clip englobed in acrylic resin. The unetched sample revealed lightly deformed $\mathrm{CuS}$-inclusions of about $20-30 \%$ of total deformation. Some of the inclusions also contain up to $2 \%$ of Sn. Etching the sample with Klemm II revealed heavy coring, indicating a non-homogenous alloy (Fig. 5f). The etchant developed undeformed, equiaxed grains of $\alpha$-solid 
solution with twins of about ca $30 \times 40 \mu \mathrm{m}$ in diameter. No $(\alpha+\delta)$ eutectoid of the $\mathrm{Cu}$-Sn system remained, indicating longer or more frequent annealing followed by cold deformation. In the final working step, the belt clip was shortly annealed. In the corrosion, $\mathrm{Ni}$ and $\mathrm{Sb}$ were enriched. The corrosion follows both the dendritic structure and grain boundaries and intracrystalline dislocations (annealing twins and strain lines) of single grains. The hardness values of 92-128 HV correspond to annealing applied as a final working step.

\section{Prigglitz, inv. no. UF-22692.1652-A, belt clip}

The belt clip is made of tin-bronze with about $8 \% \mathrm{Sn}, 0.6 \%$ $\mathrm{S}$ (EDXS), $0.2 \% \mathrm{Fe}$, and $0.4 \% \mathrm{Sb}$. Nickel and As are also present in trace amounts, and $\mathrm{Ag}$ and $\mathrm{Pb}$ were not detected. One end of the belt clip was pinched off, and the crosssection of the belt clip englobed in acrylic resin. Unetched, the sample revealed elongated $\mathrm{CuFeS}$-inclusions of about $30-40 \%$ of total deformation. The inclusions also contain lesser amounts of Sb. Etching the sample with Klemm II revealed heavy coring, indicating an inhomogeneous alloy. The etchant developed small, ca $25 \times 35 \mu \mathrm{m}$ in diameter, equiaxed grains of $\alpha$-solid solution with twins (Fig. 6a). No $(\alpha+\delta)$ eutectoid of the $\mathrm{Cu}$-Sn system remained, indicating longer or more frequent annealing followed by cold deformation. As the final working step, the belt clip was shortly annealed. Under polarized light and supported by EDXS analyses, copper carbonates and oxides are present, as are various tin oxides. Corrosion in the sample follows both the dendritic structure and grain boundaries and intracrystallinearly between the dislocations (annealing twins) of single grains. The hardness values of 96-110 HV correspond to annealing in the final working step.
Fig. 6 Microstructures. Belt clip inv.no. UF-22692.1652 from Prigglitz: a Etched with Klemm II. Coring and fine equiaxed grains of $\alpha$-solid solution with annealing twins. Rod inv.no. UF-22692.912 from Prigglitz: b Etched with Klemm II; much $(\alpha+\delta)$ eutectoid and $\mathrm{Cu}$-drops are visible. c SEM image. Note the $\mathrm{Cu}$-drops and the massive $(\alpha+\delta)$ eutectoid. Wire ID S013 from Kammerwandgrotte: $\mathbf{d}$ Etched with ferric chloride. Complete cross-section. Note the smaller grain size on the outside. Prigglitz, bracelet (inv.no. UF-22692.1780): e Unetched. Note the copper drop and the presence of $(\alpha+\delta)$ eutectoid. The CuFeSinclusions are not deformed. Pottschach, pin (inv.no. 72.488): f Etched with ferric chloride
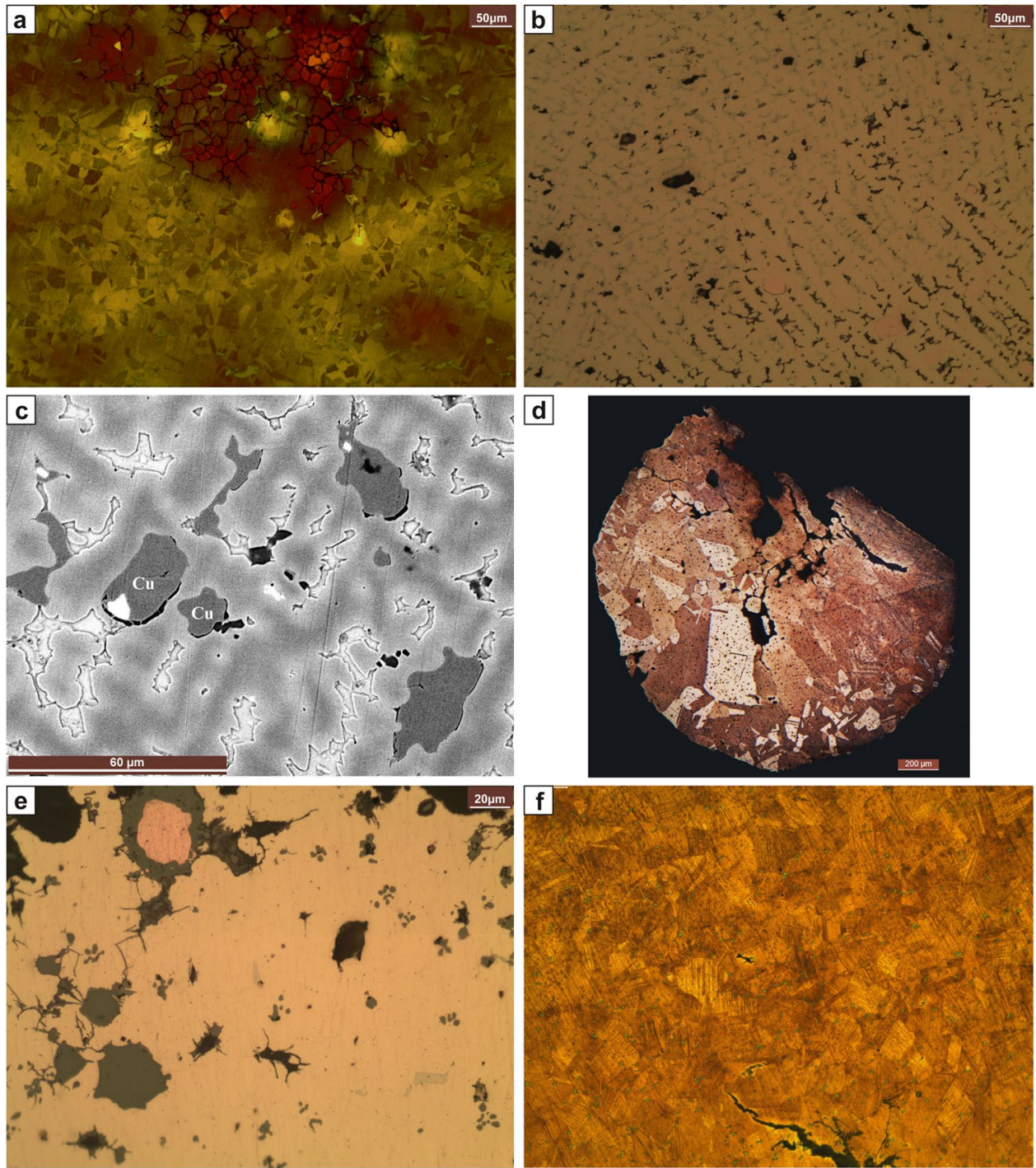


\section{Prigglitz, inv. no. UF-22692.912, rod/wand}

The rod is made of tin-bronze with about $12 \% \mathrm{Sn}, 0.5 \% \mathrm{~S}$ (EDXS), and $0.6 \% \mathrm{~Pb}$. Nickel and $\mathrm{Sb}$ are present in trace amounts, while Fe, As, and Ag were not detected. A crosssection of one end of the rod was englobed in acrylic resin. The unetched sample shows a porous, as-cast, dendritic microstructure with a few globular CuS-inclusions and high amounts of $(\alpha+\delta)$ eutectoid in the Sn-rich zones of the alloy. The eutectoid may also contain some Fe. Of particular importance are the drops of pure $\mathrm{Cu}$ surrounded by $\mathrm{CuS}$-inclusions (Fig. $6 \mathrm{~b}-\mathrm{c}$ ). These $\mathrm{Cu}$-drops indicate that not all of the $\mathrm{Cu}$ was dissolved entirely when the molten alloy was poured into the form. In the corrosion, copper and tin oxides were noted, while the CuS-inclusions were usually not corroded. The hardness values of 176-245 HV are relatively high and relate both to the high amount of brittle — but hard $(\alpha+\delta)$ eutectoid (Mödlinger and Sabatini 2017) - and the high amount of $\mathrm{Sn}$ in the alloy. In comparison, hardness measurements in the centre of one of the $\mathrm{Cu}$-drops showed $88 \mathrm{HV}$. It is also possible that a Sn-rich area beneath the $\mathrm{Cu}$-drop was struck during measuring.

\section{Kammerwandgrotte, ID S013, wire}

The wire is made of a $12 \%$ tin-bronze with about $0.5 \% \mathrm{~S}$ (EDXS), $0.1 \% \mathrm{Fe}$, and $0.2 \% \mathrm{Sb}$. Other elements, such as $\mathrm{Ni}, \mathrm{As}$, and $\mathrm{Pb}$, are present in trace amounts. Silver was not detected, and $\mathrm{S}$ and $\mathrm{Fe}$ are mainly present in globular CuFeSinclusions. These inclusions also contain some $\mathrm{Pb}$. Etching the sample with ferric chloride revealed polyhedric grains of different sizes with annealing twins and strain lines. The latter are only present in the smaller grains (Fig. 6d). The wire is porous and cracked in the sampled area, even though it was subjected to light deformation. The slight deformation also resulted in smaller grains close to the surface and bigger ones in the wire's centre. Corrosion in the sample follows the inter- and intracrystalline structures, especially in the sample's centre, consisting mainly of copper oxides (cuprite) and carbonates (azurite, malachite). Hardness differs significantly from grain to grain. While the bigger grains in the sample centre are rather soft (81-103 HV), the smaller ones on the edge are much harder (122-170 HV).

\section{Prigglitz, inv. no. UF-22692.1780, bracelet}

The bracelet is made of tin-bronze with about $12.8 \% \mathrm{Sn}$, $0.7 \% \mathrm{~S}$ (EDXS), and $0.1 \% \mathrm{Fe}$ and $\mathrm{Sb}$. Nickel is present in trace amounts. One end of the bracelet was pinched off, and the cross-section englobed in acrylic resin. Unetched, the sample revealed globular CuFeS-inclusions and $(\alpha+\delta)$ eutectoid of the $\mathrm{Cu}-\mathrm{Sn}$ system that contains up to $0.8 \%$ $\mathrm{Sb}$. Etching the sample with ferric chloride and Klemm II revealed coring and $25-40 \mu \mathrm{m}$ equiaxed grains of $\alpha$-solid solution with twins. The presence of the $(\alpha+\delta)$ eutectoid indicates a low temperature $\left(<520^{\circ} \mathrm{C}\right)$ or shorter annealing time at higher temperatures. Of particular importance are the drops of pure $\mathrm{Cu}$ in the sample surrounded by $\mathrm{CuFeS}$ inclusions (Fig. 6e). The drops indicate that not all of the $\mathrm{Cu}$ was completely dissolved when the molten alloy was poured into the form. In the final working step, the bracelet was annealed. The corrosion follows both the dendritic structure and grain boundaries and intracrystallinearly between the dislocations (annealing twins) of single grains. As seen under polarized light, and according to the EDXS analyses, both copper carbonates and oxides (shiny, dark-red cuprite crystals) were present, as were various tin oxides. The hardness values of 96-151 HV are in good agreement with an as-cast and annealed $14 \%$ tin-bronze.

\section{Pottschach, inv. no. 72.488 , pin}

The pin is made of tin-bronze with about $9.2 \% \mathrm{Sn}, 0.4 \%$ $\mathrm{S}$ (EDXS), $0.1 \% \mathrm{Fe}$, and $\mathrm{Sb}$. Nickel, $\mathrm{As}, \mathrm{Ag}$, and $\mathrm{Pb}$ are present in trace amounts. The sample was taken from the shaft of the pin, and the cross-section englobed in acrylic resin. The unetched sample revealed CuS-inclusions with a maximum total deformation of about $10 \%$. Porosity in the sample significantly increased towards the centre, corresponding to the centre of the pin shaft. Etching the sample with ferric chloride and Klemm II revealed coring and $25-40 \mu \mathrm{m}$ equiaxed grains of $\alpha$-solid solution with twins and strain lines (Fig. 6f). The absence of the $(\alpha+\delta)$ eutectoid indicates high temperature or more prolonged annealing. As a final working step, the pin shaft was cold deformed. Corrosion in the sample does not follow the dendritic structure or grain boundaries, or individual grain dislocations (annealing twins and strain lines). Instead, it follows a more irregular pattern typically seen in microbial-induced corrosion (Piccardo et al., 2013). As seen under polarized light, and according to the EDXS analyses, both copper carbonates and oxides (cuprite crystals) are present, as are various tin oxides. Interestingly, the copper oxides form layers on the pin's shaft surface, while the carbonates are close to the core. The hardness values of 160-193 HV are in good agreement with a cold deformed, previously as-cast and annealed $11 \%$ tin-bronze.

\section{Discussion}

All of the axes and chisels in this study are made of tinbronze with varying amounts of Sn ranging from 7.5 to $10 \%$. They all show coring, indicating that both the duration and 


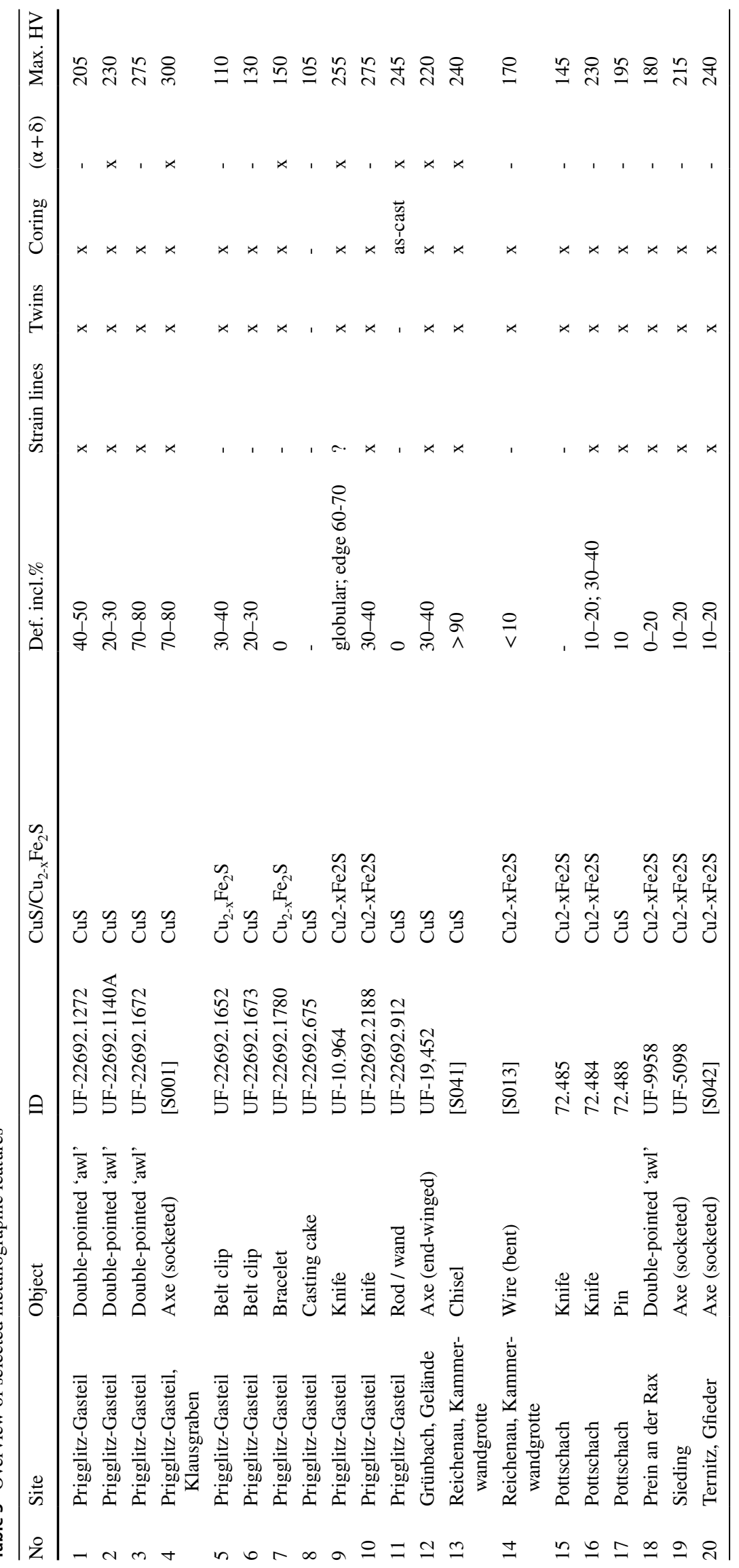


temperature of the annealing process were insufficient to homogenize the alloy (Table 3). However, all of the axes and chisels showed equiaxed grains of $\alpha$-solid solution with twins and strain lines, indicating cold deformation in the final working step due to annealing. CuS-inclusions were found in axes S001 (Prigglitz), S079 (Grünbach am Schneeberg), and the chisel from Kammerwandgrotte, and all other axes contained $\mathrm{CuFeS}$-inclusions. The total amount of deformation for the axes on their edges was astonishingly low overall (usually $<10 \%$ ), with only axe S001 showing $70-80 \%$ of total deformation in combination with $(\alpha+\delta)$ eutectoid. The axe also had the highest hardness values of all the objects ( $300 \mathrm{HV}$ at the edge). Similarly, the chisel showed a significant total amount of deformation of the edge (ca 90\%), and in combination with the presence of $(\alpha+\delta)$ eutectoid, it had high hardness values $(240 \mathrm{HV})$. The hardness values are directly related to the alloy choice, the total amount of deformation, and especially the deformation applied in the final working step. The influence of the final working step on the end product is demonstrated by the socketed axe from Ternitz (10-20\% total deformation) and the chisel (90\% total deformation and its eutectoid). Both bronzes contain similar amounts of $\mathrm{Sn}$ and $\mathrm{Fe}$, but the socketed axe underwent a higher degree of final deformation than the chisel, which resulted in far higher final hardness.

Four tin-bronze knives - two from Pottschach and two from Prigglitz - were studied. All four of them contain relatively high amounts of $\operatorname{Sn}$ (9 to 15\%). Moreover, one of the two Pottschach knives contains 1.2\% Sb. All four knives contain $\mathrm{S}$ and $\mathrm{Fe}$, which are mainly present in the CuFeSinclusions. The four knives differ in their post-casting treatment, however. While one knife from Prigglitz (inv. no. 10.964) showed a high amount of total deformation and was cold worked after several annealing/cold deformation steps, which is evident by higher hardness and finer grains, the other (inv. no. UF-22692.2188) showed less total deformation but a higher final cold deformation. The second knife's treatment resulted in higher hardness values on the edge, even though its tin-amount is much lower (10 versus 15\%). Noteworthy, the blade of knife inv.no. 10.964 broke once, was shortened, and attached to a new handle.

The two Pottschach knives show less total deformation than the ones from Prigglitz. Also, knife 72.484 shows slight deformation indications in the final working step and reaches an edge hardness of $230 \mathrm{HV}$. Knife 72.485 does not show any indications of final deformation; here, annealing was the last working step, resulting in low hardness values of $145 \mathrm{HV}$ or less. The presence of undissolved copper grains in the matrix of knife 72.485 indicates the use of 'fresh' copper and tin to produce the alloy or the addition of 'fresh' copper to a recycled tin-bronze. All knives show a low amount of total deformation in the core area (max. 20\%). While the Pottschach knives and one from Prigglitz (inv. no. UF-22692.2188) are not significantly deformed on the edge, Prigglitz knife 10.964 shows $60-70 \%$ of total deformation but less final deformation than the other one from the same site. In combination with the high amounts of Sn and $\mathrm{Fe}$, the result is a relatively high hardness of over $250 \mathrm{HV}$ on the edge. The Prigglitz knife inv. no. UF-22692.2188 shows the knives' highest hardness value with up to $274 \mathrm{HV}$ (edge) and up to $193 \mathrm{HV}$ (core; ca $2 \mathrm{~mm}$ from the edge). The higher $\mathrm{HV}$ is due to the final deformation applied in the last working step. Hardness values are higher on the edges of three knives (UF-22692.2188, 10.964, 72.484), while one knife shows a uniform distribution of similar values (knife 72.485). Again, these measurements are in good agreement with the observed microstructures and annealing in the last assumed working step.

Four tin-bronze double-pointed awls - three from Prigglitz and one from Prein - were studied. While two of the awls from Prigglitz are made of tin-bronze with about $10 \%$ Sn, the third (inv. no. UF-22692.1672) contains more than 14\%. The awl from Prein contains far less at ca 5\%. All four awls contain $\mathrm{S}$, which is mainly present in the CuSinclusions, and $\mathrm{Fe}$ was only detected in trace amounts in the awl from Prein. Interestingly, As and Ag were not detected in any of the awls, Ni at trace amounts in two (Prigglitz UF-22692.1672 and Prein) and Sb at about 0.1\% in three (Prigglitz UF-22692.1672 and UF-22692.1140A, and Prein). The awl from Prein showed a relatively high amount of $\mathrm{Pb}$ at $0.7 \%$, and of the other awls, only the Prigglitz UF-22692.1672 showed traces of $\mathrm{Pb}$. The four awls were studied metallographically and are characterized by very pure $\mathrm{Cu}$ in their production. The four awls, however, do not differ in their post-casting treatment but do in its intensity. All but one awl (inv. no. UF-22692.1672) showed heavy coring. While three awls show a total amount of deformation of about $0-50 \%$ in the sampled area, only inv. no. UF-22692.1672 showed a much higher level of deformation at $70-80 \%$. All four were cold deformed, and annealed, with cold deformation being the last step of production. In one of the awls (inv. no. UF-22692.1140A), the $(\alpha+\delta)$ eutectoid is still present, indicating short, low-temperature annealing, followed by cold deformation. The Prigglitz awl inv. no. UF-22692.1672 shows the highest hardness value of them all at $274 \mathrm{HV}$. This is due to the intensive total, and especially the final, deformation and the higher amount of $\mathrm{Sn}$ in the alloy. The other two awls from Prigglitz had a maximum HV of 230 (inv. no. UF-22692.1140A) and 205 (inv.no. UF-22692.1272). In agreement with the low amount of $\mathrm{Sn}$ in the alloy and the low total and final deformation, the Prein awl showed the lowest hardness values between 160-181 HV.

The final annealing of both belt clips makes sense since a final cold deformation would have increased their brittleness. Belt clips need to be flexible. The clips' production and their 
hardness values are very similar, as is their chemical composition with the exception of Ag in clip UF-22692.1673, which contains about $0.3 \%$ while none was detected in clip UF-22692.1652. Concerning the rod/wand studied, a freshly produced $\mathrm{Cu}-\mathrm{Sn}$ alloy is presumed, or adding 'fresh' $\mathrm{Cu}$ to an already existing and recycled tin-bronze, as the microstructure shows not-dissolved $\mathrm{Cu}$-drops, often surrounded by $\mathrm{CuS}$-inclusions. Neither Fe, As, or Ag were detected. The tin-bronze wire was cast and, after some deformation and following annealing, slightly deformed. The bracelet was also cast and slightly deformed and then annealed. Drops of pure $\mathrm{Cu}$ indicate that not all of the $\mathrm{Cu}$ was dissolved entirely when the molten alloy was poured into the form. The bracelet was annealed for a short time at lower temperatures in the final working step, as $(\alpha+\delta)$ eutectoid is still present. The pin was annealed and only slightly deformed after casting. The absence of the $(\alpha+\delta)$ eutectoid indicates high temperature or more extended annealing. As a final working step, the pin shaft was cold deformed.

Of particular interest are the undissolved drops of $\mathrm{Cu}$ in the CuSn-matrix, which were found in every fifth of the objects (Ternitz, socketed axe (ID S042): twinned grain; Pottschach, knife (72.485): grain; Prigglitz, rod/wand (UF22692.912): drops with surrounding CuS; and Prigglitz, bracelet (UF-22692.1780): big drops). The drops range from 5 to $35 \mu \mathrm{m}$ in diameter. Such unalloyed copper inclusions (UCI) have been noted in other archaeological bronzes (Bosi et al. 2002). The UCI observed in the four objects discussed here do not relate to corrosion, which are usually irregularly shaped from pseudo-morphically replacing other phases and are instead due to the (s)melting process itself. For the objects in this study, not all of the $\mathrm{Cu}$ was completely dissolved when the molten alloy was poured into the casting mould.

The CuS-layers around the copper drops of the rod/ wand (UF-22692.912) suggest the copper drops might have already formed during the smelting process (Bosi et al. 2002). Above $1105^{\circ} \mathrm{C}, \mathrm{Cu}$ and $\mathrm{S}(<20 \%)$ are immiscible with a top layer of $\mathrm{Cu}_{2} \mathrm{~S}$ and a bottom layer of $\mathrm{Cu}$ with about $2 \% \mathrm{~S}$ (copper-rich $\mathrm{Cu}-\mathrm{S}$ solution). Upon cooling, the solid phase $\mathrm{Cu}_{2} \mathrm{~S}$ and the copper-rich $\mathrm{Cu}-\mathrm{S}$ solution are present, and slagging of solid $\mathrm{Cu}_{2} \mathrm{~S}$ takes place to obtain high-purity copper. During cooling, spherical particles of $\mathrm{Cu}_{2} \mathrm{~S}$ containing a copper-rich core might form, which are heavier than $\mathrm{Cu}_{2} \mathrm{~S}$ particles and therefore less likely to slag and remaining in the alloy to form UCI (Bosi et al. 2002). While singular copper drops in crystallized form were noted for socketed axe (ID S042) and the knife (72.485), many of them with up to $35 \mu \mathrm{m}$ diameter, and most had already oxidized to $\mathrm{CuO}$, were noted on bracelet (UF-22692.1780). For these three objects, we can either assume that fresh copper was added to an already existing CuSn-alloy (recycling) or that the CuSn alloy was freshly produced. Hence, we can assume that objects were very much likely not made using recycled tin-bronzes.

Regarding the objects' function, all cutting edge objects were worked to improve their material properties, especially their edge hardness. Hardness values differed for the jewellery, except for the pin where the last working step was annealing, and hardness values are thus comparatively low at between 110 and $170 \mathrm{HV}$. These values suggest that elasticity was more important than hardness. Only the as-cast rod/ wand from Prigglitz shows relatively higher hardness values, which are related to the presence of the eutectoid.

Concerning cutting edge objects (axes, chisels, and pickaxe), hardness values range from 215 to $300 \mathrm{HV}$, highlighting that the material properties of the edges were intentionally improved for an ideal usability of the tools. The only exception is knife 72.485 from Pottschach with 145 HV.

Hardness values depend on various factors such as alloy composition, thermal treatment, and deformation applied. For the objects studied, this is particularly the $\mathrm{Sn}$ and $\mathrm{Fe}$ content. The presence of Fe, even at values as low as $0.15 \%$, also reduces formability and causes cracks and surface defects (see Nerantzis 2015; Papadimitriou 2008). It also influences the eutectoid and, most importantly, the final deformation treatment that was applied. As no direct correlation between $\mathrm{Fe}$ or $\mathrm{Sn}$ content, final deformation, and hardness values were detected (likely also related to the low number of samples), we assume that Bronze Age smiths simply stopped at a certain point during the final working step (cold deformation) once they reached a (for them) sufficiently good result. This does not necessarily need to be the highest possible hardness of the alloy, as was also observed often at Early Bronze Age axes from north Alpine regions (Kienlin 2008).

\section{Conclusions}

The Late Bronze Age site of Prigglitz-Gasteil is considered a regional centre of copper production and bronze working based on the evidence of an openwork copper ore mine and a nearby bronze casting workshop. Metallographic analyses of different cutting tools and jewellery items from PrigglitzGasteil, and six contemporaneous sites in the surrounding region, provide insights into the post-casting treatment of different kinds of bronze objects. This information helps us understand the overall chaîne opératoire in metal production, which is important in identifying local metalworking traditions.

As discussed in detail, objects with a cutting edge were worked according to their function. For instance, the sharp edges of axes and knives and the points of the awls had undergone annealing and cold deformation cycles with cold deformation as the final step in almost all cases. This 
sequence of treatments resulted in higher hardness. The total deformation on blade edges ranged from 10 to $20 \%$ (one awl, two socketed axes), 30-50\% (end-winged axe, two awls, two knives), 60-70\% (one knife, one awl, one socketed axe), and beyond (chisel with over 90\%). Interestingly, these objects' alloys do not seem to have been chosen intentionally to include higher Sn concentrations except for awl UF-22692.1672 and knife 10.964 from Prigglitz.

Small jewellery objects, such as the belt clips, the bracelet, and wire, which need to have a certain amount of flexibility to function, were worked far less with a total amount of deformation of $0-40 \%$. Their last working step was annealing, which resulted in higher flexibility and lower hardness. Comparatively, the pin from Pottschach received a final cold deformation treatment, resulting in higher hardness. Also of note, the hardness of the as-cast $12 \%$ tin-bronze rod/wand fragment from Prigglitz is due to the presence of $(\alpha+\delta)$ eutectic with $245 \mathrm{HV}$.

There was no distinct difference in quantity and quality of post-casting treatments for the objects from the sites surrounding the Prigglitz-Gasteil mine. A pattern that seems to arise, albeit with the limited number of samples investigated, suggests that the Prigglitz region's bronze production was not standardized. Alloys do not seem to have been explicitly chosen for particular object types or their intended function; however, this conclusion should be revisited as additional samples are investigated in the future. Finally, it is worth mentioning that four out of the 20 studied objects (Ternitz, socketed axe; Pottschach, knife; and Prigglitz, rod/wand and bracelet) contain unalloyed copper inclusions, which are most likely related to the incomplete mixing of scrap metals and alloys during recycling.

Acknowledgements This project was funded by the Austrian Science Fund (FWF), project no. P30289-G25 ('Life and Work at the Bronze Age Mine of Prigglitz'). We would like to thank Hofrat Dr. Anton Kern, the head of the Prehistoric Department at the Museum of Natural History, Vienna, and Hofrat Dr. Ernst Lauermann, former head of the Prehistoric Department at the State Collections of Lower Austria, who both kindly permitted us to sample the objects. Chemical analyses (XRF) were carried out at the Curt-Engelhorn-Zentrum Archäometrie in Mannheim, Germany, by Dr. Daniel Berger.

Author contribution MM: Data curation; Investigation; Methodology; Original draft; Conceptualization; Analysis interpretation; Writing of 'Methodology', 'Results', 'Discussion', and 'Conclusions'. PT: Funding acquisition; Project administration; Writing of 'Introduction', 'Selected objects and their site context', and 'Conclusions'.

Funding Open access funding provided by Università degli Studi di Genova within the CRUI-CARE Agreement.

Open Access This article is licensed under a Creative Commons Attribution 4.0 International License, which permits use, sharing, adaptation, distribution and reproduction in any medium or format, as long as you give appropriate credit to the original author(s) and the source, provide a link to the Creative Commons licence, and indicate if changes were made. The images or other third party material in this article are included in the article's Creative Commons licence, unless indicated otherwise in a credit line to the material. If material is not included in the article's Creative Commons licence and your intended use is not permitted by statutory regulation or exceeds the permitted use, you will need to obtain permission directly from the copyright holder. To view a copy of this licence, visit http://creativecommons.org/licenses/by/4.0/.

\section{References}

Bosi C, Garagnani GL, Imbeni V, Martini C, Mazzeo R, Poli G (2002) Unalloyed copper inclusions in ancient bronze artefacts. J Mater Sci 37:4285-4298. https://doi.org/10.1023/A:1020640216415

Calliano G (1894) Prähistorische Funde in der Umgebung von Baden, Wilhelm Braumüller, Wien, Leipzig

Czajlik Z (2013) Lokaler, regionaler oder Fernhandel? Probleme der spätbronzezeitlichen Metallversorgung am Velem-St. Veit-Berg (Westungarn). In: Rezi B, Németh RE, Berecki S (eds) Bronze age crafts and craftsmen in the Carpathian Basin. Proceedings of the international colloquium from Târgu Mureş, 5-7 October 2012, Editura MEGA, Târgu Mureş, p 167-180

Czajlik Z (2014) Traces of prehistoric smelting workshops in the Carpathian Basin. In: Berecki $S$ (ed) Iron age crafts and craftsmen in the Carpathian Basin. Proceedings of the international colloquium from Târgu Mureş, Editura MEGA, Târgu Mureş, p 139-146

Hampl F, Mayrhofer R (1963) Urnenfelderzeitlicher Kupferbergbau und mittelalterlicher Eisenbergbau in Niederösterreich. 2. Arbeitsbericht über die Grabungen d. NÖ. Landesmuseums 1953-1959. Archaeologia Austriaca 33:50-106

Haubner R, Strobl S, Trebsche P (2019) Metallographic analyses from the late Urnfield period copper mining settlement at PrigglitzGasteil in Lower Austria. In: Turck R, Stöllner T, Goldenberg G (eds) Alpine Copper II - Alpenkupfer II - Rame delle Alpi II Cuivre des Alpes II. VML Verlag Marie Leidorf GmbH, Bochum, New Results and Perspectives on Prehistoric Copper Production, pp 323-332

Hottwagner F, Lang R (1999) KG Reichenau. Fundberichte aus Österreich 38:779

Ilon G (1992) Keftiubarren ingot from an Urn-Grave Culture settlement at Gór-Kápolndadomb (C. Vas). Acta Archaeologica Academiae Scientiarum Hungaricae 44:239-259

Ilon G (1996) Beiträge zum Metallhandwerk der Urnenfelderkultur - Gór (Komitat Vas, Ungarn). Vorläufiger Bericht. In: Jerem E, Lippert A (eds) Die Osthallstattkultur. Akten des Internationalen Symposiums, Sopron, 10.-14. Mai 1994, Archaeolingua Alapítvány, Budapest, p 171-186

Ilon G (2018) Újabb velemi urnamezős kori öntőformák. A Szent Vid-i és a góri fémmûves központ jelentôsége az urnamezős kori Kárpát-medencében (Further moulds of the Urnfield period found in Velem. The importance of metalworking at Szent Vid and Gór). Savaria 40:115-135

Jiráň L (2002) Die Messer in Böhmen, Prähistorische Bronzefunde VII,5 (Stuttgart)

Kerchler H (1960) Grabreste der Urnenfelderkultur aus Pottschach. B. H. Neunkirchen. NÖ. Archaeologia Austriaca 28:36-43

Kienlin TL (2008) Frühes Metall im nordalpinen Raum. Eine Untersuchung zu technologischen und kognitiven Aspekten früher Metallurgie anhand der Gefüge frühbronzezeitlicher Beile. Universitätsforschungen zur prähistorischen Archäologie 162. Bonn: Habelt

Lang R (2000) KG St. Johann am Steinfelde, Fundberichte aus Österreich 39:599 
Lauermann E, Rammer E (2013) Die urnenfelderzeitlichen Metallhortfunde Niederösterreichs. Mit besonderer Berücksichtigung der zwei Depotfunde aus Enzersdorf im Thale, Verlag Dr. Rudolf Habelt, Bonn

Lochner M (2004) Tongussformen für Ringe aus urnenfelderzeitlichen Siedlungen Niederösterreichs. Archaeologia Austriaca 88:103-120

Lochner M (2013) Bestattungssitten auf Gräberfeldern der mitteldonauländischen Urnenfelderkultur. In: Lochner M, Ruppenstein F (eds) Brandbestattungen von der mittleren Donau bis zur Ägäis zwischen 1300 und 750 v. Chr. Akten des internationalen Symposiums an der Österreichischen Akademie der Wissenschaften in Wien, 11.-12. Februar 2010, Wien, p 11-31

Lochner M (2017) Thunau am Kamp - eine befestigte Höhensiedlung der Urnenfelderkultur. Grundlagen und aktuelle Forschungsergebnisse. In: Loznjak Dizdar D (ed) The late Urnfield Culture between the Eastern Alps and the Danube. Proceedings of the International Conference in Zagreb, November 7-8, 2013, Zagreb, p 7-24

Lutz J, Pernicka E (1996) Energy Dispersive X-Ray Fluorescence Analysis of Ancient Copper Alloys: Empirical Values for Precision and Accuracy. Archaeometry 38:313-323

Mayer EF (1977) Die Äxte und Beile in Österreich, Prähistorische Bronzefunde IX/9, München

Mödlinger M, Trebsche P (2020) Archaeometallurgical investigation of a Late Bronze Age hoard from Mahrersdorf in Lower Austria, Journal of Archaeological Science: Reports 33, 102476

Mödlinger M, Trebsche P, Sabatini B (2021) Chemical and isotopical characterization of a new Late Bronze Age mining site in Prigglitz, Lower Austria. PLOS one (accepted)

Mödlinger M, Sabatini, B. (2017) Bronze Age Caucasian metalwork: alloy choice and combination. Journal of Archaeological Science: Reports 16:248-257. https://doi.org/10.1016/j.jasrep. 2017.10.018

Mödlinger M, Piccardo P (2013) Manufacture of Eastern European decorative discs from 1200 BC. Journal of Archaeological and Anthropological Sciences 5(4):299-309. https://doi.org/10. 1007/s12520-012-0111-6

Mühlhofer F (1952) Die Forschung nach urgeschichtlichem Bergbau im Gebiet der Hohen Wand in Niederösterreich. Archaeologia Austriaca 9:77-88

Müller R (2006) Die Struktur des in Várvölgy am Nagy-Lázhegy erschlossenen, spätbronzezeitlichen Höhensiedlungsdetails. Zalai Múzeum 15:189-201

Nerantzis N (2015) Experimental simulation study of prehistoric bronze working: testing the effects of work-hardening on replicated alloys. In: Hauptmann A, Modarressi-Tehrani D (eds) Archaeometallurgy in Europe III. Proceedings of the 3rd International Conference, Deutsches Bergbau-Museum Bochum June 29 - July 1, 2011. Der ANSCHNITT. Beiheft 26 (Bochum), 329-336

Papadimitriou G (2008) The technological evolution of copper alloys in the Aegean during the prehistoric period. In: Tzachili I (ed) Aegean metallurgy in the bronze age: proceedings of an International Symposium held at the University of Crete, Rethymnon, Greece, on November 19-21, 2004 (Athens), 281-298

Piccardo P, Mödlinger, M, Ghiara G, Campodonico, Bongiorno V (2013) Investigation on a "tentacle-like" corrosion feature on Bronze Age tin-bronze objects. Journal of applied physics A 113/4, 1039-1047. https://doi.org/10.1007/s00339-013-7732-1

Ř́hovský J (1972) Die Messer in Mähren und dem Ostalpengebiet, Prähistorische Bronzefunde VII, 1 (München)
Ř́hovský J (1979) Die Nadeln in Mähren und im Ostalpengebiet (von der mittleren Bronzezeit bis zur älteren Eisenzeit), Prähistorische Bronzefunde XIII, 5 (München)

Sperber L (2017) Studien zur spätbronzezeitlichen Chronologie im westlichen Mitteleuropa und in Westeuropa, Monographien des RGZM 136 (Mainz)

Trebsche P (2013) Resources and nutrition in the Urnfield period mining site of Prigglitz-Gasteil in Lower Austria - Preliminary report on the excavations from 2010 to 2012. In: Anreiter P, Brandstätter K, Goldenberg G, Hanke K, Leitner W, Nicolussi K, Oeggl K, Pernicka E, Schaffer V, Stöllner T, Tomedi G, Tropper P (eds) Mining in European history and its impact on environment and human societies - proceedings for the $2^{\text {nd }}$ mining in European history conference of the FZ HiMAT, 7.-10. November 2012, Innsbruck, p 33-37

Trebsche P (2015a) Urnenfelderzeitlicher Kupferbergbau in Niederösterreich. In: Stöllner T, Oeggl K (eds) Bergauf Bergab. 10.000 Jahre Bergbau in den Ostalpen. Wissenschaftlicher Beiband zur Ausstellung im Deutschen Bergbau-Museum Bochum vom 31.10.2015-24.04.2016. Im vorarlberg museum Bregenz vom 11.06.2016-26.10.2016, Verlag Marie Leidorf, Bochum, p 209-214

Trebsche P (2015b) Zur Absolutdatierung der urnenfelderzeitlichen Kupfergewinnung im südöstlichen Niederösterreich, Archäologisches Korrespondenzblatt 45, 41-59

Trebsche P, Fehlmann D, Konrad M (2019) 12 urnenfelderzeitliche Bronzefunde $=1$ Depot vom "Gelände" bei Grünbach am Schneeberg?, in: Hye, S., Töchterle, U. (Eds.), UPIKU:TAUKE. Festschrift für Gerhard Tomedi zum 65. Geburtstag, Habelt, Bonn, p 559-569

Trebsche P, Pucher E (2013) Urnenfelderzeitliche Kupfergewinnung am Rande der Ostalpen. Erste Ergebnisse zu Ernährung und Wirtschaftsweise in der Bergbausiedlung von Prigglitz-Gasteil (Niederösterreich). Prähistorische Zeitschrift 88:114-151

Veliačik L (2012) Nože z doby bronzovej na Slovensku, Slovenská Archeológia 60, 285-342.Zachar, T, Salaš, M (2018). Proveniencia medenej suroviny na Morave $\mathrm{v}$ mladšej dobe bronzovej na príklade kovových depotov z Blučiny a Borotína (The provenance of copper ore in Moravia in the Late Bronze Age based on metal hoards from Blučina and Borotín). Archeologické Rozhledy 70:39-66

Zachar T, Salaš M (2018) Proveniencia medenej suroviny na Morave v mladšej dobe bronzovej na príklade kovových depotov z Blučiny a Borotína (The provenanceof copper ore in Moravia in the Late Bronze Age based on metal hoards from Blučina and Borotín). Archeologické Rozhledy 70:39-66

Zachar T, Salaš M (2019) Př́íspěvek k problematice distribuce středoslovenské mědi na Moravě v mladší době bronzové na př́kladě kovových depotů Blučina 1 a Blučina 13 (Contribution to the issue of the distribution of copper from central Slovakia in Moravia in Late Bronze Age on the example of the metal hoards Blučina 1 and Blučina 13). Archeologické Rozhledy 71:615-640

Publisher's note Springer Nature remains neutral with regard to jurisdictional claims in published maps and institutional affiliations. 